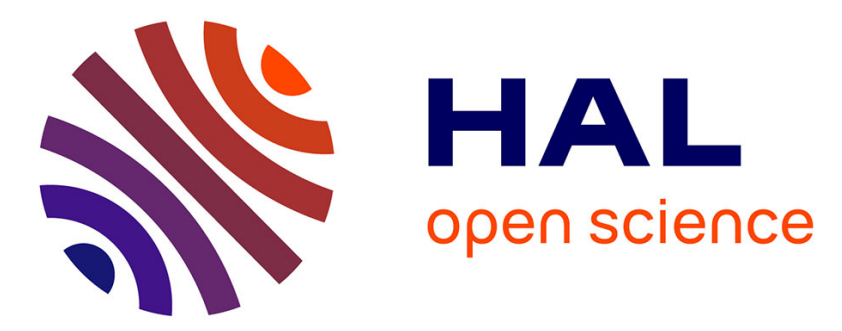

\title{
Sediment damage caused by gas exsolution: A key mechanism for mud volcano formation
}

Arthur Blouin, Nabil Sultan, Jean-Paul Callot, Patrice Imbert

\section{To cite this version:}

Arthur Blouin, Nabil Sultan, Jean-Paul Callot, Patrice Imbert. Sediment damage caused by gas exsolution: A key mechanism for mud volcano formation. Engineering Geology, 2019, 263, pp.105313. 10.1016/j.enggeo.2019.105313 . hal-02377189

\section{HAL Id: hal-02377189 \\ https://hal.science/hal-02377189}

Submitted on 21 Dec 2021

HAL is a multi-disciplinary open access archive for the deposit and dissemination of scientific research documents, whether they are published or not. The documents may come from teaching and research institutions in France or abroad, or from public or private research centers.
L'archive ouverte pluridisciplinaire HAL, est destinée au dépôt et à la diffusion de documents scientifiques de niveau recherche, publiés ou non, émanant des établissements d'enseignement et de recherche français ou étrangers, des laboratoires publics ou privés.

\section{다)(1) $(5$}

Distributed under a Creative Commons Attribution - NonCommercial| 4.0 International 
Version of Record: https://www.sciencedirect.com/science/article/pii/S0013795219309676

Keywords: consolidation testing; gas exsolution; gassy sediments; sediment damage; mud volcano

Highlights: exsolution and subsequent mud generation at depth from stratified sediments.

- Fracture geometry is controlled by the degree of gas saturation and preconsolidation pressure

- Gas exsolution provokes sediment damage and change in mechanical behavior

- Sediments do not recover their initial behavior completely after reloading

- Gas exsolution is able to generate mud from compacted sediments

Gas was generated in the samples by circulating carbonated water through the fine-grained sediments, then decreasing the total pressure. Particular attention was given to the impact of gas saturation and associated damage and fractures on P-wave velocity, sediment compressibility, permeability and preconsolidation pressure. Results show that fracture geometry is mainly controlled by the degree of gas saturation and preconsolidation pressure. The damage level increases with the degree of gas saturation while the elastic modulus of sediments is degraded. Experimental data show that sediments do not entirely recover their original mechanical behavior when gas dissipates. Finally, the experimental data confirm that gas exsolution and expansion is a key mechanism for mud generation. 
Sediments partially saturated with free gas are a widespread occurrence and are found in varying marine environments (Grozic, et al., 2000). Nageswaran (1983) discriminates between two free-gas distributions: continuous gas phase and discrete separated gas bubbles. The latter is defined as gassy sediments and Nageswaran (1983) gives a maximum limit in terms of the degree of gas saturation $\left(\mathrm{S}_{\mathrm{g}}<15 \%\right)$. Gassy sediments are a well-known issue in marine geotechnics that has been studied for decades as the detection and quantification of free-gas content is essential for geohazard assessment (Esrig \& Kirby, 1977; Sobkowicz \& Morgenstern, 1984; Thomas, 1987; Sultan, et al., 2004, 2012; Judd \& Hovland, 2007; Riboulot, et al., 2013).

The main difficulty when studying gassy fine-grained sediments in laboratory is to obtain a discrete distribution of gas bubbles. Several techniques exist, including the generation of free gas through the zeolite molecular sieve technique (Nageswaran, 1983; Thomas, 1987; Wheeler, 1988; Sills, et al., 1991; Nava Castro, et al., 2013), the generation of biogenic gas through bacteria (Sills \& Gonzalez, 2001; Rebata-Landa, et al., 2012) and finally the generation of gas bubbles through the circulation of overpressured carbonated water followed by decompression (Grozic, et al., 2000; Sultan, et al., 2012).

The mechanical behavior of gassy sediments has been extensively studied over the last decades (Thomas, 1987; Wheeler, 1988; Sills, et al., 1991; Helgerud, et al., 1999; Grozic, et al., 2005; Sultan, et al., 2012; Nava Castro, et al., 2013; Jang \& Santamarina, 2014). P-wave velocity attenuation is a typical feature of all gassy sediments (Sills, et al., 1991; Helgerud, et al., 1999; Sultan, et al., 2012). Thomas (1987) shows that fine-grained gassy sediments subjected to consolidation behave like a water-saturated soil with discrete compressible solid inclusions modeling the gas bubble compressibility. Moreover, several studies show that the compressible gas bubbles deform under applied stresses causing a delay in the consolidation process and therefore a change in sediment compressibility (Sills, et al., 1991; Grozic, et al., 2005; Nava Castro, et al., 2013; Liu, et al., 2016). Additionally, numerous experiments and numerical simulations show that the presence of discrete gas bubbles that nucleated directly in the sediments decrease its permeability (Egermann \& Vizika, 2000; Naylor, et al., 2000; Jang \& Santamarina, 2014). Revil et al. (1998) even shows that the formation of capillary seals can generate an effective permeability lower than intrinsic sediment permeability. Furthermore, Sultan, et al. (2012) show the important drop in preconsolidation pressure proving that fine-grained sediments are damaged after gas exsolution. Finally, Wheeler (1988), Lunne, et al. (2001), Hight, et 
al. (2002), Sultan \& Garziglia (2014) and Hong et al. (2017) demonstrate that the undrained shear strength of fine-

56 grained gassy sediments is also impacted by the presence of free gas.

Mud volcanoes are one of the most spectacular geological features related to gas venting. Gas, mostly methane and carbon dioxide, is expelled at the seafloor along with a fluid mélange, varying in proportion, of water, 59 fine-grained sediments and larger rock fragments (Kopf, 2002; Mazzini \& Etiope, 2017). Mud is commonly sourced 60 from depths of several kilometers (Stewart \& Davies, 2006; Kirkham, 2015; Blouin, et al., 2019). The Lusi catastrophe, 61 ongoing since 2006, allowed to monitor mud volcano formation from its initiation (Tingay, et al., 2008, 2017; Mazzini, 62 et al., 2012). Tingay et al. (2017) demonstrated that the key parameters of the Lusi triggering were the high overpressure and the gas influx into weak layers. Moreover, Capaccioni et al. (2017) show that the emplacement of 64 sand volcanoes during Cone Penetration Testing in Italy was caused by gas exsolution and expansion in loose deposits. 65 Therefore, Tingay et al. (2015) and Blouin et al. (2019) proposed gas exsolution and expansion triggered by 66 hydrofracturing and the subsequent drop in pore fluid pressure as mud generation mechanisms.

The aim of this study is to identify the impact of gas expansion and exsolution on the mechanical behavior of 68 fine-grained sediments sampled directly on the active Absheron Mud Volcano (AMV - South Caspian Basin; Blouin et 69 al., 2019). Particular attention was given to the gas impact on sediment structure, acoustic properties (P-wave 70 velocity), compressibility and preconsolidation pressure by carrying out a series of consolidation/compressibility tests 71 using a novel experimental set-up. The main questions motivating this work are summarized below:

If gas exsolution within fine-grained sediments is already proven to cause damage (Sultan, et al., 2012), what 73 are the controlling parameters dominating the process and what are the consequences in terms of hydromechanical 74 behavior?

Do the mechanical properties of the sediments recover from gas exsolution/expansion after mechanical 76 reloading? 


\subsection{Properties of tested soil and sample preparation}

To identify the potential geohazard of the AMV, Fugro conducted an offshore geotechnical survey in 2014

(Dan \& Po, 12/09/2017, pers. com.) including rotary drilling with sediment coring up to 34 meters deep (Figure 1 for

location) and in situ CPTu measurements (Cone Penetration Testing, with piezocone; Lunne, 2010; Boggess \& the natural and remolded sediments.

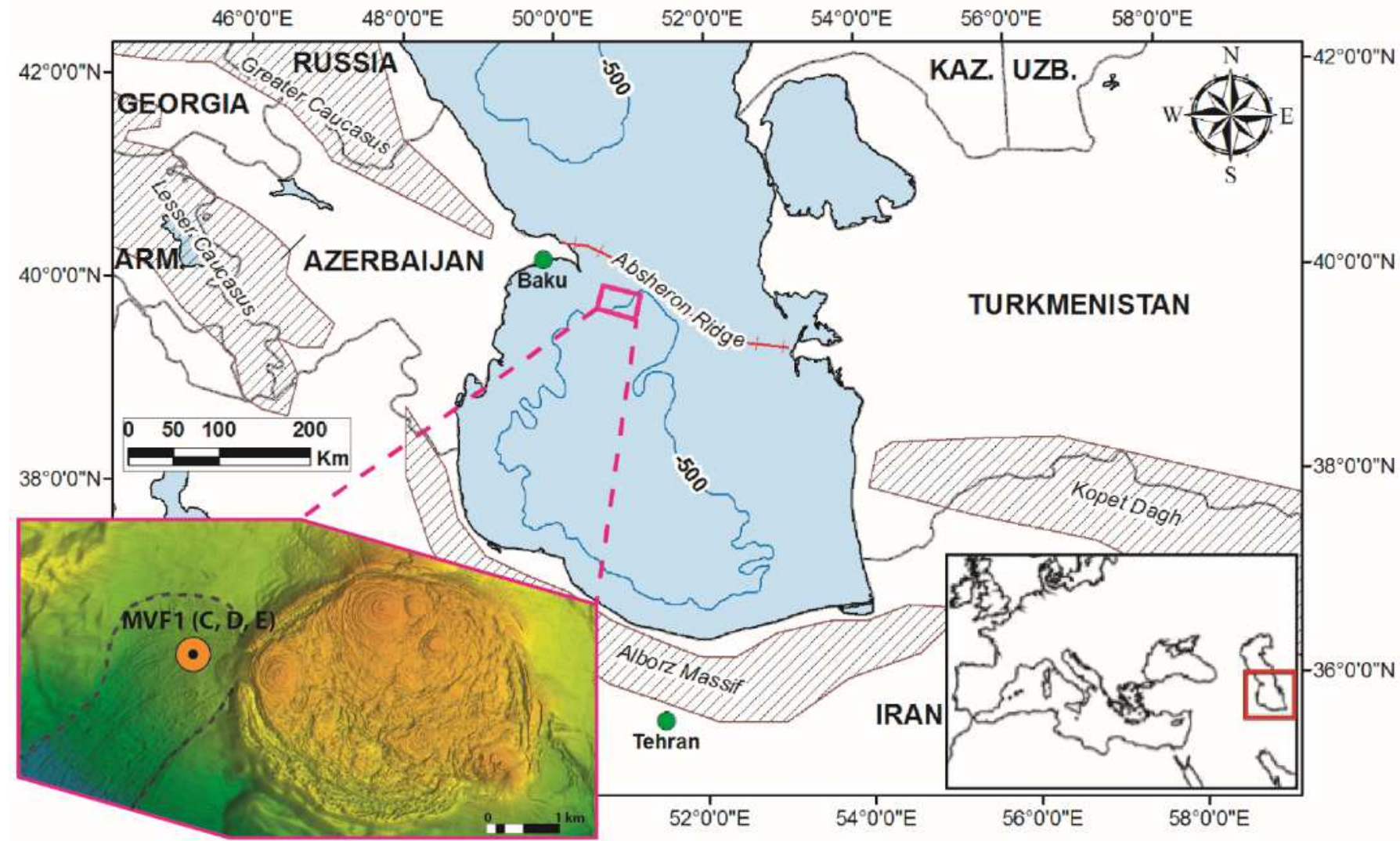

Figure 1: Location of the study area. The Absheron Mud Volcano is located on the Absheron anticline (purple rectangle), $100 \mathrm{~km}$ to the SE of Baku, North of the South Caspian Basin. Details of the seafloor morphology of the area surrounding the mud volcano is given in the inset in the bottom left hand corner (read Blouin et al. (2019) for more details). The rotary drilling MVF1, located on the mudflow, is also displayed.

CPTu profiling and sediment type classification acquired at the MVF1 drilling site, on the western mudflow of

the AMV (Dan \& Po, 12/09/2017, pers. com.) show the presence of three different mechanical intervals. For this study, and in order to carry out basic geotechnical analyses, we selected three samples from the three different intervals (MECA-6, MECA-15 and MECA-22; Table 1).

Grain size distribution was determined with a laser diffraction apparatus (Mastersizer 3000, Ryzak \&

Bieganowski, 2011). Results show that the three reference samples have roughly the same grain size distribution with 
peak values between 4 and $6 \mu \mathrm{m}$ and a minor signature around $400 \mu \mathrm{m}$ (Figure 2a). However, the MECA-6 sample is slightly poorer in the fine fraction and richer in the coarser fraction. The $d_{x}$ is the grain size where $\mathrm{X} \%$ of the grains are finer. The three samples differentiate on the coarser fraction as their $d_{10}$ and $d_{50}$ are roughly the same (Table 2 ).

Nevertheless, all the samples have a $d_{90}$ greater than $35 \mu \mathrm{m}$, meaning that $90 \%$ of the particles are smaller than $35 \mu \mathrm{m}$.

$50 \%$ of the mud particles are smaller than $5 \mu \mathrm{m}$. Therefore, the studied samples are essentially composed of silts and clay-size particles with a minor fraction of very fine to medium sand.

\begin{tabular}{|c|c|c|c|c|c|}
\hline Core Name & Sample Name & $\begin{array}{l}\text { Type of } \\
\text { sample }\end{array}$ & Type of analysis & $\begin{array}{c}\text { Water } \\
\text { depth }(m)\end{array}$ & $\begin{array}{l}\text { Depth Below } \\
\text { Seafloor }(m)\end{array}$ \\
\hline \multirow{8}{*}{ MVF1C } & MECA-1 & Core Sample & Consolidation cell & \multirow{8}{*}{521} & 0.3 \\
\hline & MECA-2 & Core Sample & Consolidation cell & & 1.0 \\
\hline & MECA-3 & Core Sample & Consolidation cell & & 2.0 \\
\hline & MECA-4 & Core Sample & Consolidation cell & & 2.2 \\
\hline & MECA-5 & Core Sample & Consolidation cell & & 3.0 \\
\hline & MECA-6 & Core Sample & $\begin{array}{c}\text { Grain size distribution, oedometer } \\
\text { and mineralogy }\end{array}$ & & 3.6 \\
\hline & MECA-7 & Core Sample & Consolidation cell & & 4.0 \\
\hline & MECA-8 & Core Sample & Consolidation cell & & 4.8 \\
\hline MVF1D & MECA-15 & Core Sample & Grain size distribution, oedometer & 522 & 10.0 \\
\hline \multirow[t]{2}{*}{ MVF1E } & MECA-22 & Core Sample & $\begin{array}{c}\text { Grain size distribution, oedometer } \\
\text { and mineralogy }\end{array}$ & \multirow[t]{2}{*}{522} & 33.1 \\
\hline & MECA-23 & Core Sample & Consolidation cell & & 39.6 \\
\hline
\end{tabular}

A mineralogical analysis was performed on two of the samples used in this study (MECA-6 and MECA-22, see

Table 1). Table 2 displays the main mineralogical fractions for the two tested samples grouped into three poles: quartz, clays and calcite. Other mineral types were distributed between the pole according to their density or their mineral group. For instance, the dolomite percentage was added to the calcite pole, and apatite to the clay pole.

The Atterberg limits were determined using the fall cone method (Feng, 2000). Results are presented in Table 2. Sediments from the three samples have a mean plastic limit value of $\left(w_{P}\right) 20.3 \%$, a mean liquid limit $\left(w_{L}\right)$ of $43 \%$ and a mean plasticity index (PI) of $22.7 \%$.

Oedometer tests were carried out on the same reference samples using incremental loading according to the ASTM D-2435 method (ASTM International, 1996). Three oedometer reference samples were prepared from three 
mud samples (MECA-6, MECA-15, MECA-22; Table 1) with a water content of approximately 1.5 the liquid limit $\left(w_{L}\right)$. Compressibility curves during loading and unloading tests are plotted in Figure $2 \mathrm{~b}$. The three samples have almost the same virgin consolidation curve with a compression index $C_{c}$ of 0.3 and a swelling index $C_{s}$ of 0.08 (Table 2).
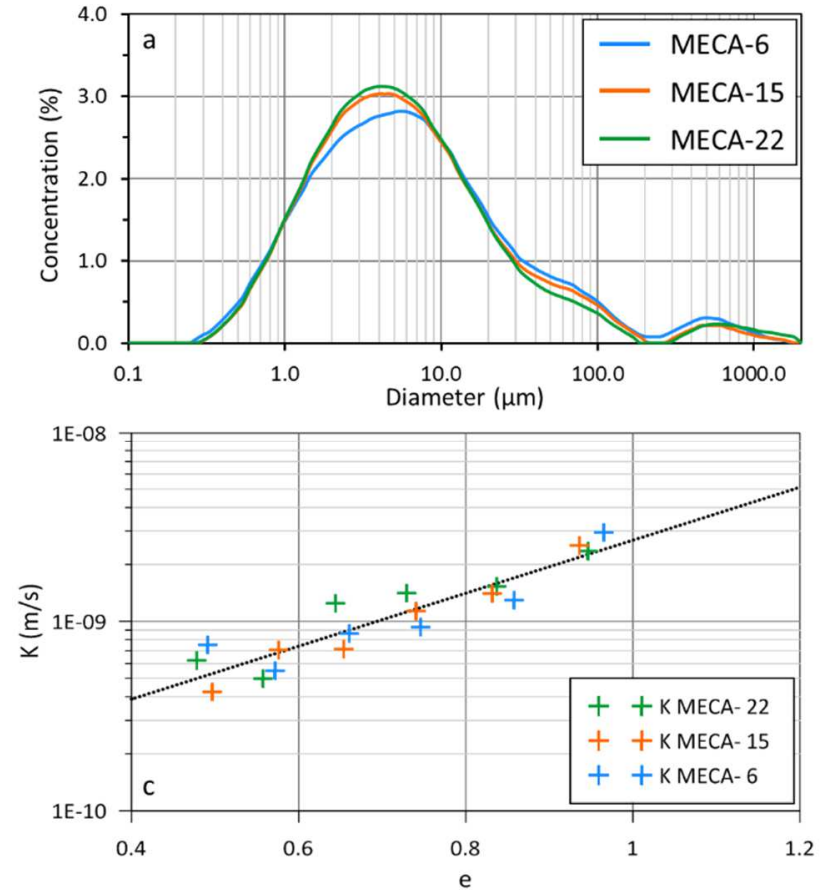

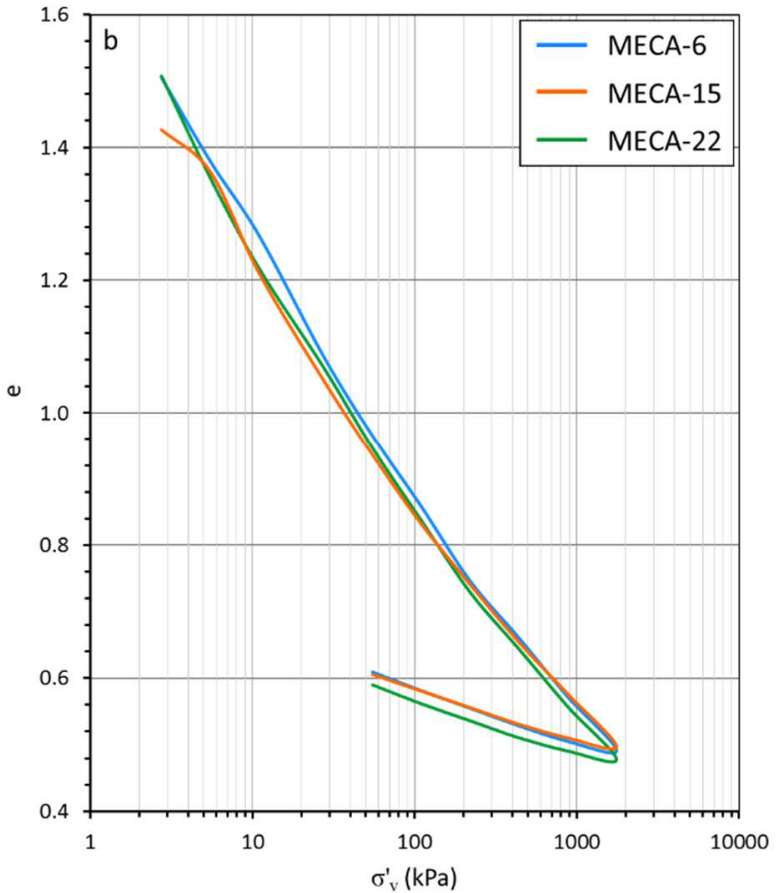

Figure 2: Basic properties of the tested three water-saturated samples. a: grain size distribution. b: oedemeter compressibility and c: hydraulic conductivity versus void ratio.

During consolidation tests, hydraulic conductivity measurements were carried out using the falling-head test method. Figure 2 c summarizes the results as a cross-plot of hydraulic conductivity versus void ratio. The three samples have a similar trend and hydraulic conductivity $\mathrm{K}$ stands between $8.10^{-8}$ and $7.10^{-9} \mathrm{~m} / \mathrm{s}$ for void ratios between 1 and 0.4. Skempton (1944) gives an empirical expression linking the compression index and the liquid limit of remolded clays. Using the mean liquid limit of the tested sediment, the calculated $C c$ is 0.32 , which agrees with values obtained using oedometer tests (Table 2).

Due to the insignificant variability of the basic properties of the three tested samples, eight other samples were selected from the same three intervals of the MVF1 core in order to test the impact of gas exsolution using the new experimental apparatus developed in the present study (Table 1). To obtain homogeneous samples, the eight samples were mixed and remolded with a water content of approximately twice the liquid limit (Table 2). Remolding was carried out using a mechanical stirrer. The same slurry was used in all the tests presented in the paper. At the end of each test, a small part of the tested sample served to measure the final water content. 


\begin{tabular}{|c|c|c|c|}
\cline { 2 - 4 } \multicolumn{1}{c|}{} & MECA-6 & MECA-15 & MECA-22 \\
\hline $\mathrm{d}_{10}(\mu \mathrm{m})$ & 1.17 & 1.22 & 1.21 \\
\hline $\mathrm{d}_{50}(\mu \mathrm{m})$ & 5.91 & 5.41 & 5.23 \\
\hline $\mathrm{d}_{90}(\mu \mathrm{m})$ & 53.7 & 42.9 & 36.8 \\
\hline $\mathrm{w}_{\mathrm{p}}(\%)$ & 21.0 & 23.0 & 17.0 \\
\hline $\mathrm{w}_{\mathrm{L}}(\%)$ & 42.0 & 43.0 & 44.0 \\
\hline $\mathrm{PI}$ & 21.0 & 20.0 & 27.0 \\
\hline $\mathrm{C}_{\mathrm{c}}$ & 0.32 & 0.29 & 0.31 \\
\hline $\mathrm{C}_{\mathrm{s}}$ & 0.08 & 0.07 & 0.07 \\
\hline mass\% Quartz & 38.5 & & 36 \\
\hline mass\% Clays & 51.5 & & 55.5 \\
\hline mass\% Calcite & 10 & & 8.5 \\
\hline
\end{tabular}

Table 2: Synthesis of the main sample properties. Further details are given in Figure 2.

\subsection{Experimental set-up and calibration}

In order to analyze the gassy sediments, we developed a novel experimental set-up, composed of three main

modules (Figure 3): the consolidation cell and the mechanical press, designed to apply vertical loads, and the saturation module where water is carbonated under a given $\mathrm{CO}_{2}$ gas pressure. The last module is the control panel that connects all the experimental set-up sensors with a computer in order to constrain and record the different parameters.

The consolidation cell is composed of a Plexiglas cylinder that forms, along the two end covers, the fixed part of the system (Figure 3). The type of Plexiglas used for the consolidation cell is PMMA XT, which has an elastic modulus of 3.3 GPa and a yield stress of 70-80 MPa. The Plexiglas cylinder is $15 \mathrm{~mm}$ thick. The piston is composed of a steel rod fixed into a pierced plastic cylinder (Figure 3). Two porous stones placed on the top and the bottom of the sample ensure the consolidation of the sediment during loading. A load cell and a vertical displacement sensor allow 142 controlling the rate of displacement and the axial force applied to the sample (Figure 3). The load cell is limited to $5 \mathrm{kN}$ 143 ( $\approx 1300 \mathrm{kPa}$ considering the sample section) with a precision of $\pm 0.005 \mathrm{kN}$. A bender element system (supplied by GDS Ltd, UK; Hasan and Wheeler (2015)) is integrated into the piston and the bottom pedestal to measure P-wave velocity 

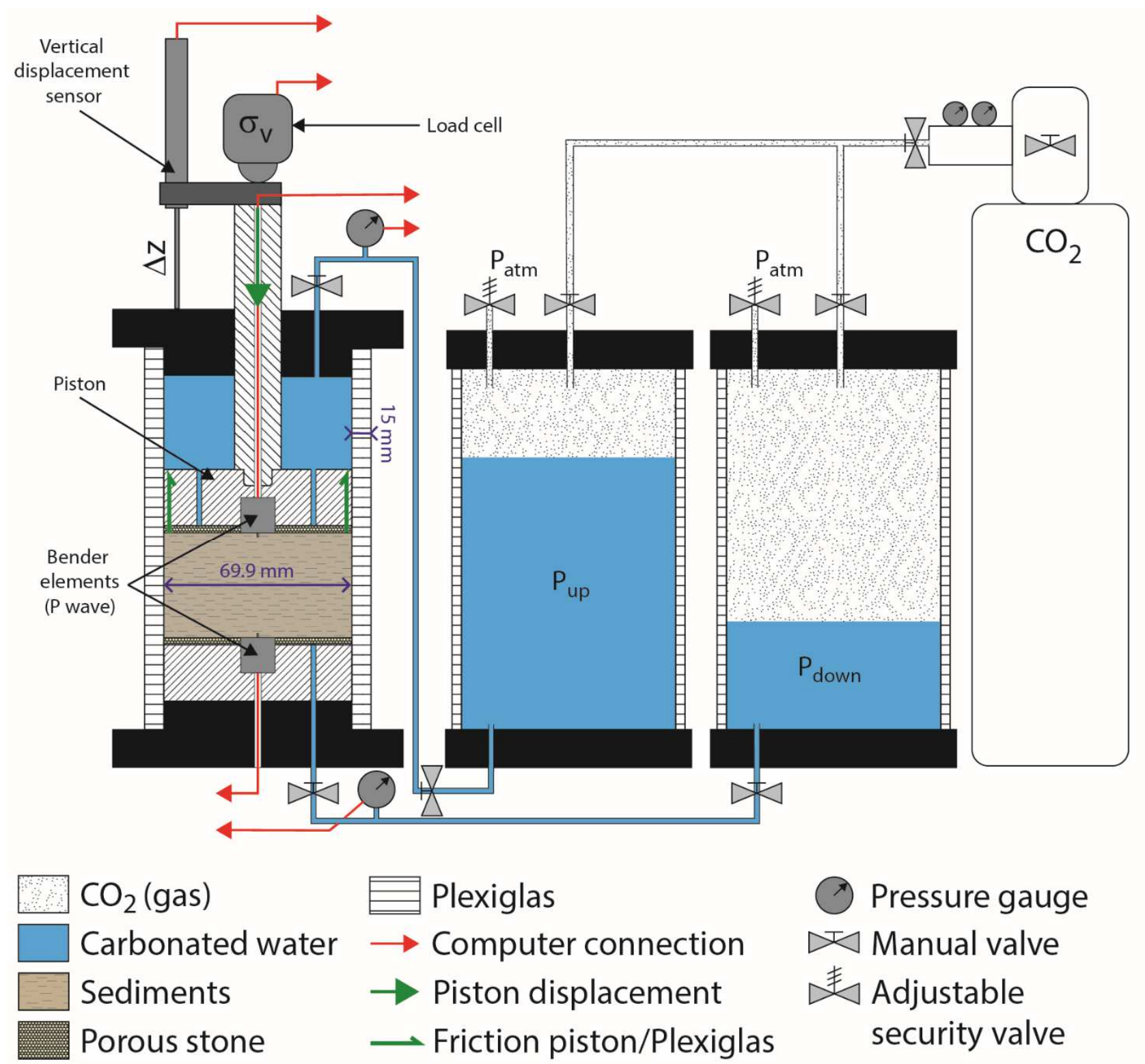

Figure 3: Detailed experimental setup showing the consolidation cell, the saturation system and the main sensors emplacement. Green arrows indicate the orientation of friction forces for a downward motion of the piston.

A lip seal circles the piston and avoids sediments flowing above the piston but generates a non-negligible friction on the inner surface of the Plexiglas cylinder. This friction is measured by the load cell and is calibrated to properly calculate the net applied vertical effective stress. Force balance at the sediment-piston contact shows that the measured force is a composition of the friction, a vertical upload force due to the different piston surfaces on which fluid pressure is applied (Figure 3), and the net applied load. Friction is always opposed to piston movement.

The lip seal is asymmetrical. Therefore, calibration of friction must be made during loading and unloading (Figure 4). To do so, the consolidation cell was filled with water and underwent different load and unload cycles at different pore water pressures. The piston velocity used in the different calibration tests is the same in the rest of our testing program: $0.12 \mathrm{~mm} / \mathrm{h}$ during loading, $0.5 \mathrm{~mm} / \mathrm{h}$ during unloading. The load velocity was determined by 

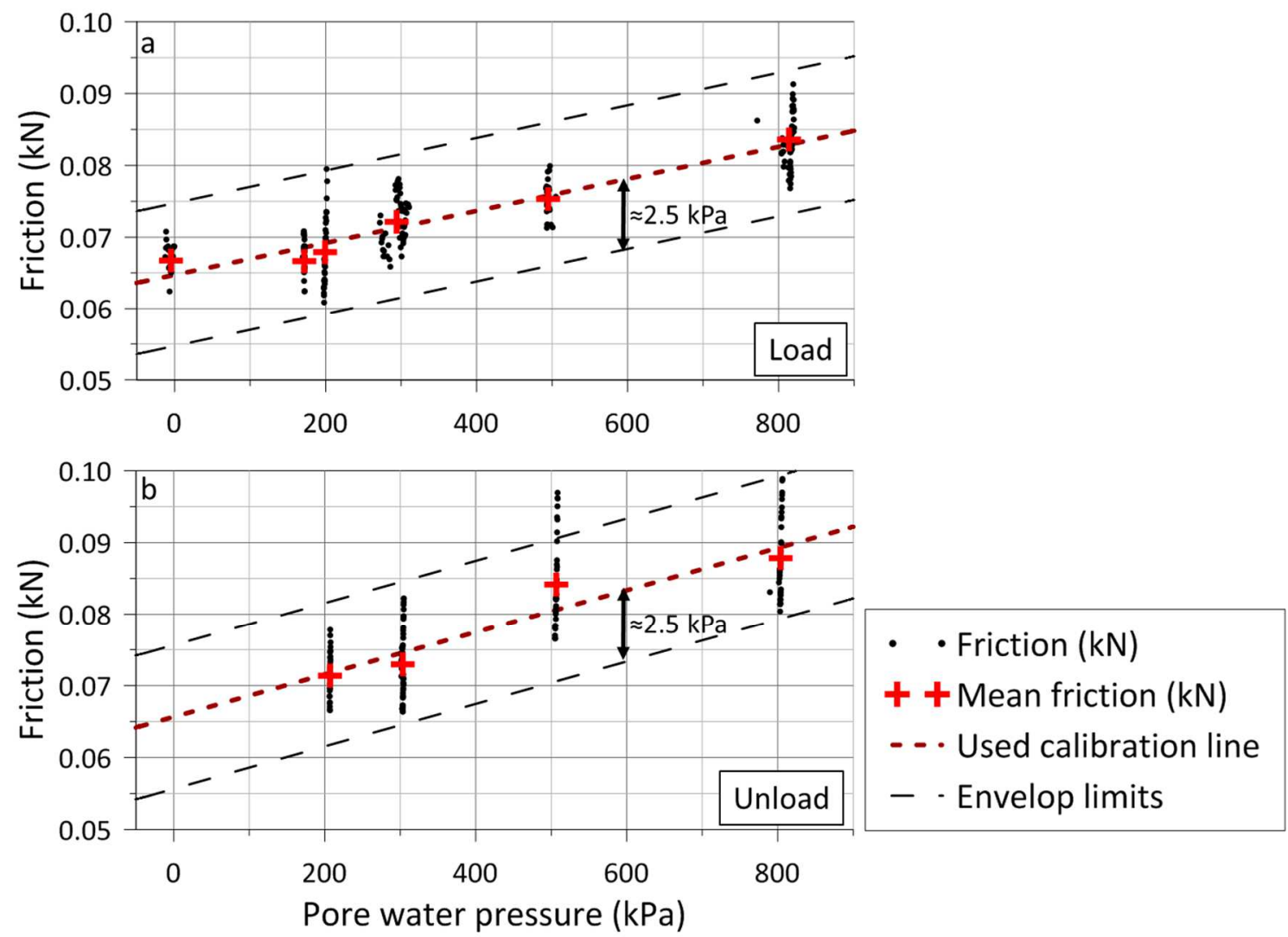

Figure 4: friction calibration during (a) loading and (b) unloading for different pore water pressures. The dotted black lines correspond to the envelop values of friction. The friction variation is within $\pm 2.5 \mathrm{kPa}$.

The results show that the friction is a linear function of pressure and differs during loading and unloading (Figure 4). For each pore water pressure, the friction variation is, for the corresponding diameter, within $\pm 2.5 \mathrm{kPa}$. The two friction laws obtained were then added to the vertical effective stress calculations. The effective stress corresponds to the net load force applied to the sediment. During loading stages, this force is calculated by subtracting friction force and the vertical upload (force resulting from the area difference between the piston top and bottom, see Figure 3) from the total measured load. During unloading stages, friction is added, as it is always oriented in the direction opposed to piston movement.

The saturation system is composed of two Plexiglas tanks, the same type as the consolidation cell, designed to support $1 \mathrm{MPa}$ of water/gas pressure (Figure 3). Both tanks are connected at the top to a $\mathrm{CO}_{2}$ bottle equipped with an adjustable pressure gauge that can deliver up to $2.5 \mathrm{MPa}$ of gas pressure (Figure 3). Tanks are half-filled with water, the other half being occupied by gas. Adjustable security valves are connected at the top of the two tanks and allow 
consolidation cell by their bottom end. Differential pressures at the top and bottom of the sample can be applied through the two tanks allowing the carbonated water to circulate through the sample.

Pressure gauges control the pore pressure and are limited to $3 \mathrm{MPa}$ with a precision of $\pm 0.75 \mathrm{kPa}$. Pressure gauges can be either isolated from the consolidation cell or isolated from the tanks thanks to valves present between the two parts of the system (Figure 3). All the sensors used (load cell, vertical displacement sensor and pressure gauges) are connected to a control panel (Figure 3). The computer monitors, records and controls the different test parameters.

A pressure generator is connected at the bottom end of the consolidation cell for water permeability measurements. The pressure generator creates a pressure gradient while measuring water volume change. Using Darcy's law, it is possible to calculate the hydraulic conductivity of the sediment. A falling head method can also be applied using the differential pressure between the two saturation tanks. Due to the large internal diameter of the saturation tanks $(91.9 \mathrm{~mm})$, only hydraulic conductivities obtained from water head variations greater than $10 \mathrm{~mm}$ are considered as accurate.

P-wave velocities are measured using GDS bender element system. Due to sample dimensions (diameter: $69.9 \mathrm{~mm}$; initial height around $65 \mathrm{~mm}$ ), it was necessary to calibrate the signal frequency to avoid a waveguide effect of the Plexiglas cell and lateral rebounds (Chan, 2012). After several tests, a frequency of $100 \mathrm{kHz}$ appeared to record the clearest received signal. To obtain repeatable and comparable measurements, the received signal is picked on the last relative minimum before the first received peak.

The main purpose of this experimental study is to evaluate the impact of gas exsolution and accumulation on the mechanical behavior of the tested sediments (e.g. compressibility, preconsolidation pressure, permeability, Pwave velocity). To do so, several loading/unloading cycles are applied during each test on water-saturated sediments and gassy sediments. Each test can be described with the following basic scheme and phases:

- Phase 1 - carbonated water: Water in the two saturation tanks is saturated with $\mathrm{CO}_{2}$ for at least two days with gas pressure between 300 and $800 \mathrm{kPa}$. During this first phase, carbonated water is isolated from the consolidation cell (valves closed at the base of the tanks, Figure 3).

- Phase 2 - saturation using carbonated water: Remolded sediments are poured into the consolidation cell and connected to the saturation cells. Differential water pressure is applied between the two saturation 
tanks, creating a hydraulic gradient and a carbonated water flow through the sediment. The aim is to replace the pure pore water initially present by carbonated water. Circulation is imposed until the carbonated water volume flow reaches the initial total sample volume. During this stage, some gravity settling of sediments can be observed.

- Phase 3 - consolidation of water-saturated sediments: The piston is manually moved until contact with sediments is established. The first loading/unloading cycle starts with a loading velocity of $0.12 \mathrm{~mm} / \mathrm{h}$ and an unloading velocity of $0.5 \mathrm{~mm} / \mathrm{h}$. A maximal total load is configured based on the target value of effective stress $\left(\sigma_{v}^{\prime}=100,200\right.$ or $\left.400 \mathrm{kPa}\right)$. Another loading/unloading cycle can be applied to record the swelling index of the sediments. During these cycles, P-wave velocity and hydraulic conductivity are regularly measured.

- Phase 4 - degassing and gas exsolution process: After unloading, the piston is manually raised to allow gas expansion/exsolution and sediment swelling. Complete or partial depressurization is applied using the two valves connected to the saturation cells (Figure 3). Both valves are opened simultaneously so that the depressurization applies on both side of the sample. The partial gas exsolution is not always visible. Therefore, free gas presence is detected by comparing P-wave velocity before and after depressurization. To ensure full degassing, this phase is maintained for around 15 hours.

Phase 5 - consolidation of gassy sediments: After degassing, contact between the piston and the sample is made manually and generally, a swelling of the sample is noted. The change in the sample height is used to calculate $S_{\mathrm{g}}$. Another loading/unloading cycle is then applied to the gassy sediments with a $\sigma_{\vee}^{\prime}$ values exceeding the one applied at phase 4. As loading increases, gas saturation is expected to decrease. During this phase, P-wave velocity and permeability are measured to determine the influence of gas saturation on both parameters.

In the case of partial degassing, the two last phases can be repeated to obtain different gas saturations during the same test. Void ratio, $e$, and gas volume $V_{g a s}$ are calculated at each time step using the initial void ratio value $\left(e_{0}\right)$ and the change in sample height. Gas saturation $S_{g}$ is calculated from pore water volume $V_{w}$ before degassing and the measured $V_{\text {gas }}$ :

$$
S_{g}=\frac{V_{g a s}}{V_{g a s}+V_{w}}
$$


In the scope of this study, eleven tests were performed, one being a normal consolidation test (no gas and under atmospheric pressure) which is the reference test for compressibility (Table 3). The good agreement between a loading/unloading curve obtained during an oedometer test (ASTM D-2435, ASTM International, 1996) and the present reference test has allowed to validate the used loading velocity. During the ten other tests, fifteen degassing were triggered under different conditions (e.g. preconsolidation pressure, initial gas pressure, $\mathbf{u}_{i}$, magnitude of depressurization, $\Delta \mathrm{u}$; Table 3). Sediment mechanical compressibility as well as P-wave velocity and hydraulic conductivity were measured before and after each degassing stage. This study contains 270 P-wave measurements and 26 hydraulic conductivity measurements (Table 3). Details of the testing program are provided in Table 3 :

\begin{tabular}{|c|c|c|c|c|c|c|c|}
\hline \begin{tabular}{|c|} 
Test \\
number
\end{tabular} & $\begin{array}{c}\text { Cycle } \\
\text { (load/unload) }\end{array}$ & $\begin{array}{l}\sigma_{\text {vmax }}^{\prime} \\
(\mathrm{kPa})\end{array}$ & $u_{i}(\mathrm{kPa})$ & $\Delta \mathrm{u}(\mathrm{kPa})$ & $\begin{array}{l}\text { Number of } \\
\text { measured } V_{P}\end{array}$ & $\begin{array}{l}\text { number of } \\
\text { measured } \mathrm{K}\end{array}$ & Comments \\
\hline \multirow{3}{*}{2} & 1 & 100 & 350 & 0 & 13 & 0 & \\
\hline & 2 & 1000 & 350 & -350 & 9 & 0 & \\
\hline & 3 & 1000 & 350 & -350 & 3 & 0 & \\
\hline \multirow{2}{*}{3} & 1 & 400 & 800 & 0 & 13 & 0 & \\
\hline & 2 & 1000 & 800 & -800 & 6 & 0 & \\
\hline \multirow{3}{*}{4} & 1 & 200 & 500 & 0 & 19 & 5 & \\
\hline & 2 & 1000 & 500 & -500 & 10 & 0 & \\
\hline & 3 & 1200 & 0 & 0 & 10 & 0 & \\
\hline \multirow{2}{*}{5} & 1 & 100 & 800 & 0 & 13 & 2 & \\
\hline & 2 & 1000 & 800 & -800 & 19 & 0 & \\
\hline \multirow{3}{*}{6} & 1 & 100 & 500 & 0 & 9 & 1 & \\
\hline & 2 & 400 & 500 & 0 & 16 & 1 & \\
\hline & 3 & 1000 & 500 & -500 & 18 & 3 & \\
\hline \multirow{3}{*}{7} & 1 & 100 & 800 & 0 & 9 & 3 & \\
\hline & 2 & 400 & 800 & 0 & 7 & 0 & \\
\hline & 3 & 1000 & 800 & -400 & 10 & 0 & \\
\hline \multirow{4}{*}{8} & 1 & 100 & 800 & 0 & 4 & 1 & \\
\hline & 2 & 400 & 800 & 0 & 3 & 0 & \\
\hline & 3 & 1000 & 800 & -300 & 8 & 0 & \\
\hline & 4 & 1200 & 500 & -500 & 3 & 3 & \\
\hline 9 & 1 & 400 & 800 & 0 & 7 & 1 & \\
\hline
\end{tabular}




\begin{tabular}{|c|c|c|c|c|c|c|c|}
\hline & 2 & 1000 & 800 & -100 & 2 & 0 & \\
\hline & 3 & 1200 & 700 & -250 & 7 & 0 & \\
\hline & 4 & 1200 & 450 & -450 & 4 & 1 & $\begin{array}{c}\text { Degassing under } \sigma_{v}^{\prime}=100 \\
\mathrm{kPa}\end{array}$ \\
\hline 10 & 1 & 1200 & 0 & 0 & 9 & 3 & $\begin{array}{c}\text { drained consolidation test } \\
\text { (reference) }\end{array}$ \\
\hline \multirow{4}{*}{11} & 1 & 400 & 800 & 0 & 8 & 1 & \\
\hline & 2 & 800 & 800 & -200 & 12 & 0 & \\
\hline & 3 & 1100 & 600 & -200 & 11 & 0 & \\
\hline & 4 & 1400 & 400 & -400 & 8 & 1 & \\
\hline
\end{tabular}

Table 3: Testing program with details on the number of loading/unloading cycles per test, the applied maximal effective stress at each stage, the initial gas pressure, the magnitude of depressurization for each exsolution.

\section{Results}

In the following, we have provided the details of three tests only as, of the eleven tests, test\#5, test\#8 and test\#11 show the main behavioral features observed. The pictures of the sample shown in the results were shot during the tests through the Plexiglas cell.

During test\#8, 4 load/unload cycles were applied on the remolded sediment sample (Figure 5a). The first two cycles were completed on the water-saturated sample under constant carbonated water pressure $\left(\mathrm{u}_{\mathrm{i}}\right)$ of $800 \mathrm{kPa}$. They showed a normal loading-unloading compressibility curve (Figure 5a). However, the beginning of loading 1 ( $\sigma_{v}^{\prime}$ lower than $20 \mathrm{kPa}$ ) differs from the reference test. The difference between the two stages is related to the applied carbonated water pressure. A reference test was applied under atmospheric pressure where normal sediment settling took place. For the other ten tests, initial loading (cycle 1) took place under a carbonated water pressure gradient. This affected the normal settling velocity and accelerated sedimentation. After the first unloading in cycle 1 , the loading in cycle 2 followed the swelling trend of the sediment until reaching preconsolidation pressure $\left(\sigma_{p 0}^{\prime}=100 \mathrm{kPa}, \sigma_{p 0}^{\prime}\right.$ will be used in the rest of paper to refer to the preconsolidation pressure that the sediment underwent over the last loading phase). From this stage, the sample recovers a normal consolidation trend following the virgin consolidation curve to a vertical effective stress of $400 \mathrm{kPa}$. The $C_{c}$ and $C_{s}$ values are comparable to those obtained from oedometer tests (Figure 2 and Table 2). 

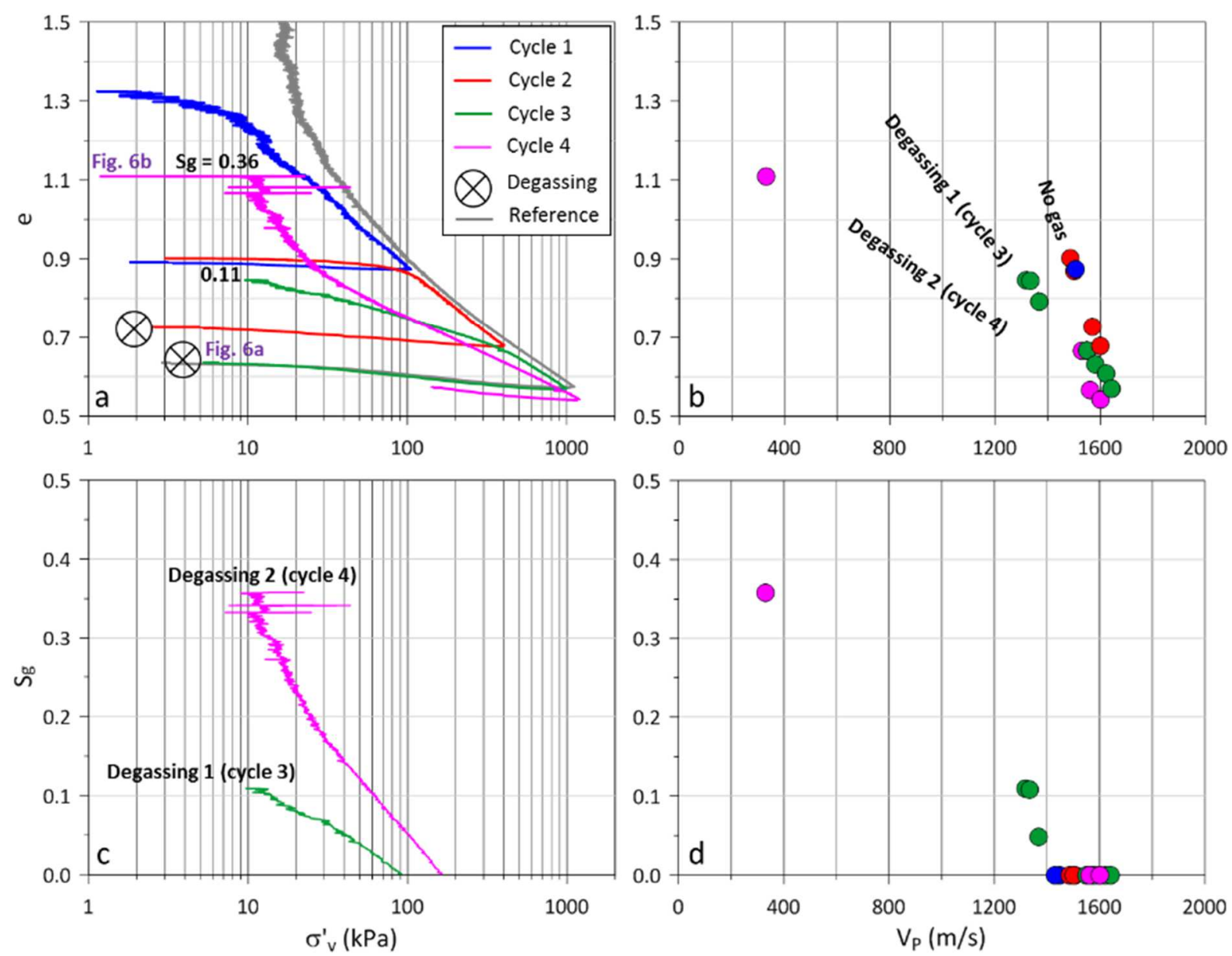

Figure 5: Results for test\#8 with 4 load/unload cycles. Each color represents a load/unload cycle. a: void ratio (e) versus vertical effective stress $\left(\sigma_{v}\right)$ b: void ratio-versus $P$ wave velocity $\left(V_{p}\right)$; c: degree of gas saturation $\left(S_{g}\right)$ versus $\sigma_{v}$ and $d: S_{g}$ versus $V_{p}$. The grey line in (a) represents the reference consolidation test.

After unloading 2, partial depressurization $(\Delta \mathrm{u})$ of $-300 \mathrm{kPa}$ was applied. No fractures or discontinuities were noticed during this phase. However, the sample swelled by $1.5 \mathrm{~mm}$, corresponding to $\mathrm{S}_{\mathrm{g}}$ of $11 \%$. The mechanical behavior after this first degassing stage changed drastically. The sample did not display an elastic trend during reloading showing a compressibility characterized by a slope varying between the swelling index and the compression index (Figure 5a). This intermediate compressibility lasted until reaching an effective stress of $400 \mathrm{kPa}$ corresponding to $\sigma_{p 0}^{\prime}$, well after gas saturation reached zero (Figure $5 \mathrm{a}, \mathrm{c}$ ). Then, the compressibility followed the normal compaction trend. P-wave velocities show a constant trend for cycles 1 and 2 (blue and red dots in Figure 5b,d) while the presence of free gas in cycle 3 causes an important decrease in P-wave velocities (green dots in Figure 5b,d). During the loading in cycle $3, \mathrm{~S}_{\mathrm{g}}$ decreases and the P-wave velocity increases and reaches normal values only when sediment behaves as a normally consolidated material.

The intermediate compressibility slope (cycle 3 between $20 \mathrm{kPa}$ and $400 \mathrm{kPa}$ in Figure 5a) was calculated and is named $\mathrm{C}_{\mathrm{cgas}}$ in all the following tests carried out in this study. For test\#8, $\mathrm{C}_{\mathrm{cgas}}$ is equal to 0.09 . The preconsolidation 
pressure was also calculated using the normal elastic curve and the virgin compression curve. The intersection between the two curves gives a preconsolidation pressure that we called $\sigma_{\mathrm{p} 2}^{\prime}$ equal to $130 \mathrm{kPa}$ which is significantly less than the applied $400 \mathrm{kPa}$ in cycle 2 (Figure 5a).

Cycle 4 began with complete depressurization $(\Delta \mathrm{u}=-500 \mathrm{kPa})$ which immediately affected the structure of the sample (Figure 6). Fractures formed during the first minutes following depressurization, ultimately showing a complete remolding of the upper part of the sample (Figure 6). Fractures are horizontally oriented in accordance with the maximum principal stress orientation. This degassing provoked a swelling of $6 \mathrm{~mm}$ of the sample partly adapted by the $\mathrm{cm}$-long and $\mathrm{mm}$-thick horizontal fractures (Figure 6). $\mathrm{S}_{\mathrm{g}}$ at this stage was found equal to 36\% (Figure 5a,c).
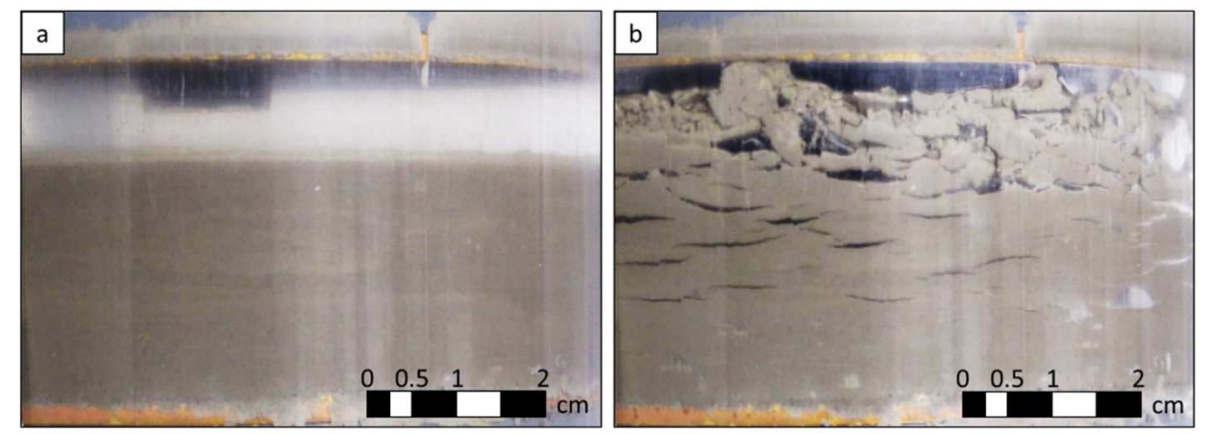

Figure 6: Pictures of the sample during test 8. a: before the second depressurization (cycle 4, Figure 5a) showing the sediment aspect before gas exsolution. b: after the second depressurization (Figure 5a). The sample swelled by $6 \mathrm{~mm}$ under the effect of gas exsolution, swelling partly due to the numerous $\mathrm{cm}$-long and mm-thick fractures.

Nageswaran (1983) gives an upper limit for gassy sediments in terms of degree of gas saturation. In this definition, sediments having $\mathrm{S}_{\mathrm{gmax}}$ higher than $15 \%$ should not be regarded as gassy sediments but as unsaturated soil. However, the gaseous phase is not homogeneously distributed and is not continuous as gas invades the sample through fracture generation (Jain \& Juanes, 2009). Moreover, once fracture opens, gas exsolution and bubble growth occur predominantly at fracture sites that act as preferential nucleation and bubble growth sites (Jang \& Santamarina, 2014; Katsman, 2015). Given the short duration of exsolution (12 hours on average), free gas does not have time to diffuse through the complete sample. Experiments by Cuss et al., (2014) demonstrated that months are needed to saturate a low-porosity sample. Therefore, free gas mainly concentrates in fracture spaces and is not present as separated spherical bubbles as in the Nageswaran (1983) definition.

The loading of cycle 4 can be divided into two stages. The first stage corresponds to the part having a compressibility slope larger than the virgin compression line. This stage corresponds to the fracture closing. Once all the fractures closed, an intermediate compressibility state, similar to that described for cycle 3 , is observed. The normal compression trend began at around $900 \mathrm{kPa}$ but is not well expressed since the test was stopped at $\sigma^{\prime}{ }_{v}$ around 
$1000 \mathrm{kPa}$. $\mathrm{S}_{\mathrm{g}}$ reached zero around $180 \mathrm{kPa}$ during the intermediate stage (Figure 5a,c). Again, a drop in P-wave velocities highlights the presence of free gas after gas exsolution (Figure $5 b, d$ ). This decrease is greater than during cycle 3 due to greater gas saturation. P-wave velocities shift from the water-saturated values even after $\mathrm{S}_{\mathrm{g}}$ reaches zero.

The slopes of the two compressibility states during reloading in cycle 4 were also measured. $\mathrm{C}_{\text {cgas }}$ equals 0.17 . The slope for the state corresponding to fracture closing is named $\mathrm{C}_{\mathrm{cfrac}}$ in the following analyses. For cycle $4, \mathrm{C}_{\mathrm{cfrac}}$ reaches 0.7 . In this cycle, two preconsolidation pressures can be calculated: $\sigma_{\mathrm{p} 2}^{\prime}$ using the method already described after fracture closing and $\sigma_{p 1}^{\prime}$ which is calculated using the intersection of the two slopes $C_{\mathrm{cgas}}$ and $\mathrm{C}_{\mathrm{cfrac}} . \sigma_{\mathrm{p} 1}^{\prime}$ was found equal to $25 \mathrm{kPa}$ while $\sigma_{\mathrm{p} 2}^{\prime}$ was not calculated because, as mentioned above, the normal compression trend is not well expressed in cycle 4.

P-wave velocities display different evolutions with void ratio depending on the cycle (Figure 5b). Cycles 1 and 2, where the measurements were made on water-saturated sample, show the same trend while the two other cycles indicate specific trends. P-wave velocities decrease with the presence of free gas (Helgerud, et al., 1999; Sultan, et al., 2012). The impact of free gas on acoustic velocities is well illustrated with test\#8 as P-wave velocity trend with void ratio have gentler slope with increasing initial gas saturation (Figure 5b). Decreased values of P-wave velocities were measured even after free gas dissipation $\left(\mathrm{S}_{\mathrm{g}}=0\right)$, and normal values were reached once sediments followed the normal compression trend (Figure 5a,b,c).

During test\#11, only one water-saturated cycle was completed, revealing that the sediments have a normal loading/unloading compressibility curve (Figure 7a). Indeed, the virgin compaction curve and the swelling trend of test\#11 perfectly fits with the drained consolidation test used as reference (Figure 7a).

After unloading 1, partial depressurization $(\Delta \mathrm{u})$ of $-200 \mathrm{kPa}$ is applied. Small and thin fractures appeared along a pre-existing weak zone that expended during gas exsolution (light color strip Figure 8a,b). At the beginning of the loading stage of cycle 2, a swelling of $5 \mathrm{~mm}$ was recorded (visible on Figure $8 \mathrm{a}, \mathrm{b}$ ), corresponding to a $\mathrm{S}_{\mathrm{g}}$ of $24 \%$ (Figure 7a). The compressibility of the gassy sediments during loading 2 is characterized by a slope comprised between $\mathrm{C}_{c}$ and $\mathrm{C}_{\mathrm{s}}$. Here again, it shows an intermediate compressibility before reaching the virgin compression curve once the $\sigma_{p 0}^{\prime}\left(400 \mathrm{kPa}\right.$ ) was exceeded (Figure 7a). $\mathrm{S}_{\mathrm{g}}$ reached zero before $200 \mathrm{kPa}$, therefore, the intermediate compressibility lasted longer than the presence of free gas in the sediments (Figure 7a,c). P-wave velocities decrease after degassing, 
compared to the trend obtained on the water-saturated sample during cycle 1 (Figure $7 b$ ). Even after the moment $S_{\mathrm{g}}$ reaches zero, P-wave velocities are attenuated, showing that gas exsolution affects them even after free gas entirely dissipated from the sample (Figure 7b,c). Finally, cycle 2 loading reached $800 \mathrm{kPa}$ before unloading the sample once again.
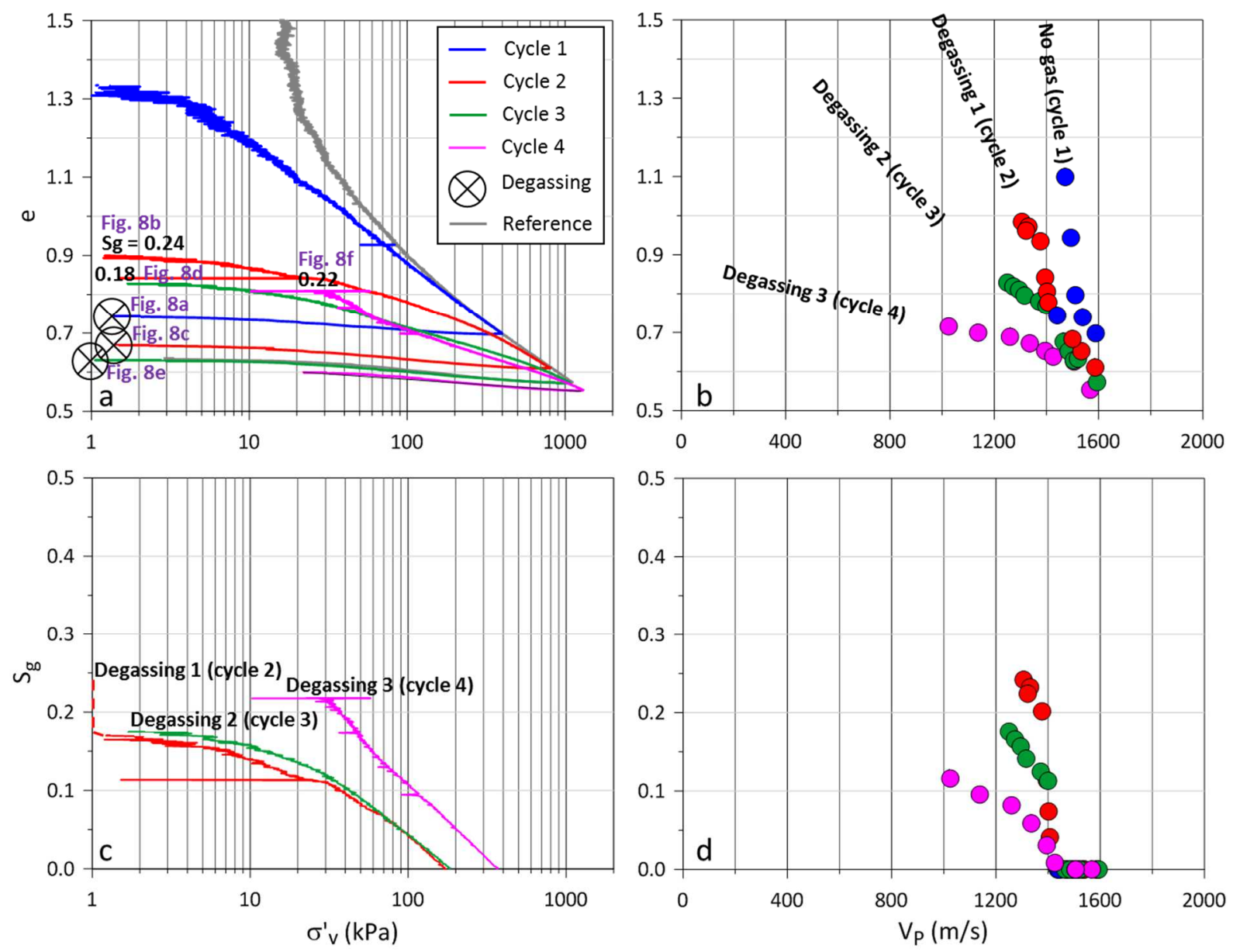

Figure 7: Results for test\#11 with 4 load/unload cycles. Each color represents one load/unload cycle. a: void ratio (e) versus vertical effective stress $\left(\sigma_{v}\right)$ b: void ratio-versus $P$ wave velocity $\left(V_{p}\right)$; c: degree of gas saturation $\left(S_{g}\right)$ versus $\sigma_{v}$ and $d: S_{g}$ versus $V_{p}$. The grey line in (a) represents the reference consolidation test.

The intermediate compressibility slope $C_{\mathrm{cgas}}$ equals 0.12 . Using the swelling and virgin compaction curves, $\sigma_{\mathrm{p} 2}^{\prime}$ was found equal to $100 \mathrm{kPa}$ (cycle 1 reached a $\sigma_{\mathrm{p} 0}^{\prime}=400 \mathrm{kPa}$ ).

Cycle 3 started after another partial depressurization of $-200 \mathrm{kPa}$ was applied. Rare and localized very thin fractures formed at the base of the sample (Figure 8c,d). No trace of the former weak strip was noticed at this stage. Additionally, $2.7 \mathrm{~mm}$ of swelling shows that free gas exsolved in the sample, resulting in a $\mathrm{S}_{\mathrm{g}}$ of $18 \%$. An intermediate compressibility is observed until the end of the loading phase. The normal compression trend began at around $900 \mathrm{kPa}$ but is not well expressed since the test was stopped at $\sigma_{v}^{\prime}$ around $1100 \mathrm{kPa}$. The gas saturation reached zero at only $200 \mathrm{kPa}$, thus most of the intermediate compressibility was measured on water-saturated sediments (Figure 7a,c). P- 
wave velocities are reduced compared to the water-saturated sediment (Figure $7 b, d)$. The depressurization of cycle 3 generated a smaller volume of free gas compared to cycle 2. Nevertheless, P-wave velocities measured during cycle 3 also decreased compared to those of cycle 2 (Figure 7b,d), showing that even after a complete cycle, sediments did not entirely recover their normal acoustic properties.
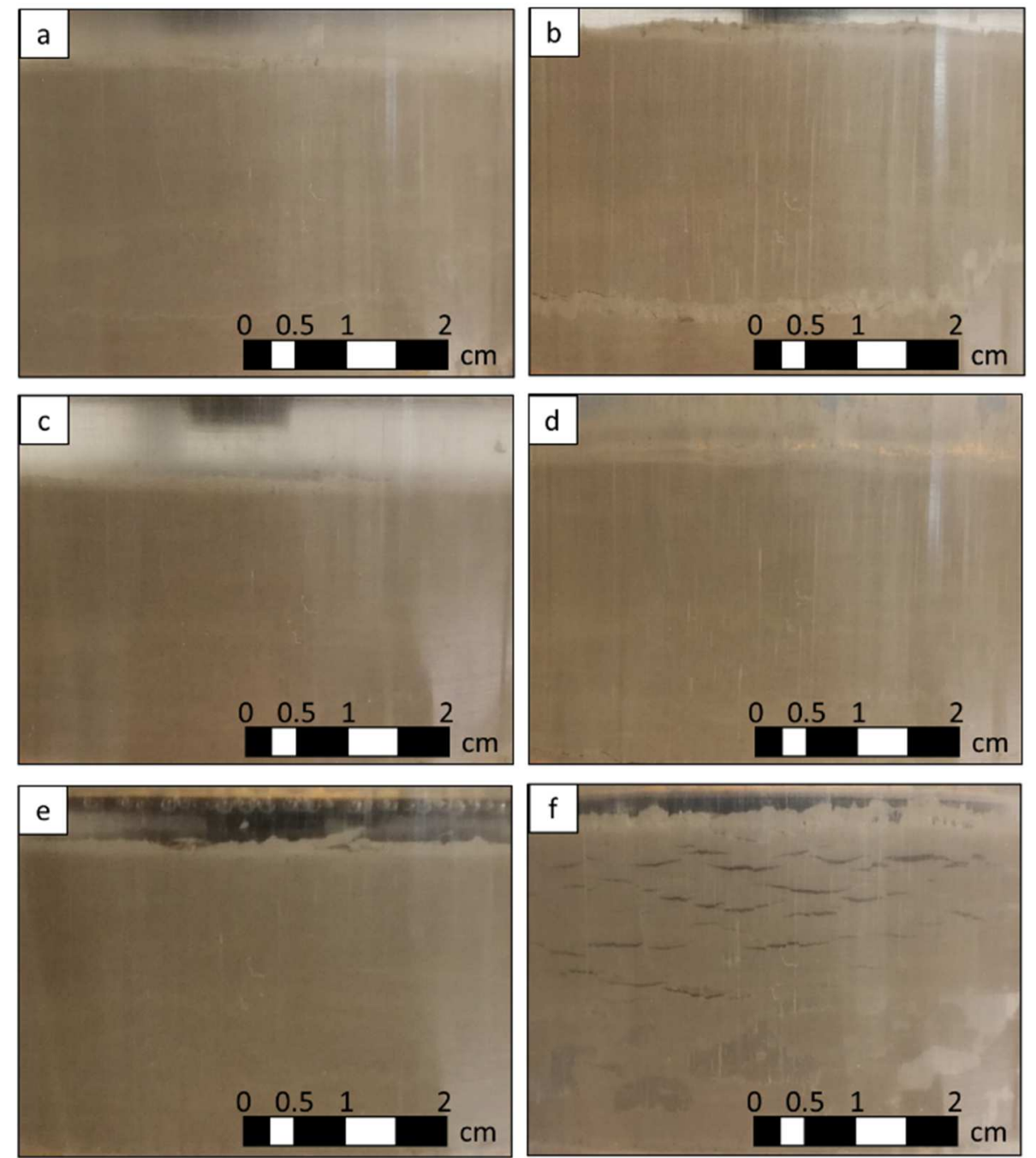

Figure 8: Pictures of the sample during test 11. a: before the second depressurization (cycle 3, Figure 7a) showing the sediment aspect before gas exsolution. b: after the second depressurization (Figure 7a). The sample swelled by $5 \mathrm{~mm}$ under the effect of gas exsolution and small and rare fractures appeared along a pre-existing weak zone (lighter color). c: before the second depressurization (cycle 3, Figure 7a) showing the sediment aspect before gas exsolution. $d$ : after the second depressurization (Figure 7a). The sample swelled by $2.5 \mathrm{~mm}$ under the effect of gas exsolution with rare and very thin fractures at the base of the sample. e: before the third depressurization (cycle 4, Figure 7a) showing the sediment aspect before gas exsolution. $f$ : after the third depressurization (Figure 7a). The sample swelled by $3.5 \mathrm{~mm}$ under the effect of gas exsolution, swelling partly due to the numerous $\mathrm{cm}$-long and $\mathrm{mm}$-thick fractures.

The intermediate compaction slope measurement resulted in a $\mathrm{C}_{\mathrm{Cgas}}$ of 0.12 and the $\sigma_{\mathrm{p} 2}^{\prime}$ of $180 \mathrm{kPa}$ when $\sigma_{\mathrm{p} 0}^{\prime}$ was $900 \mathrm{kPa}$ (cycle 2).

The final cycle started with complete depressurization $(\Delta u=-400 \mathrm{kPa})$. Figure $8 \mathrm{e}, \mathrm{f}$ shows that the sample swelled and fractured during exsolution. The fracture network is dense and composed of centimeter-long and millimeter-thick fractures. Fractures get thinner and thinner towards the base of the sample and some gas pockets are 
visible. A total swelling of $3.3 \mathrm{~mm}$ was recorded, resulting in a $\mathrm{S}_{\mathrm{g}}$ of $22 \%$. The loading of cycle 4 is divided into two stages (Figure 7a). The first stage corresponds to the part having the biggest compressibility. This stage corresponds to the fracture closing (Figure 8f). Once all the fractures closed, an intermediate compressibility state is observed. The normal compression trend began at around $1100 \mathrm{kPa}$ but is not well expressed since the test was stopped at $\sigma_{\mathrm{v}}^{\prime}$ around $1300 \mathrm{kPa}$. Sg reached zero around $\sigma_{v}^{\prime}$ of $380 \mathrm{kPa}$ during the intermediate stage (Figure 7a,c). P-wave velocities recorded during the loading following this depressurization display a strong decrease compared to the other cycle, even compared to cycle 2 during which more free gas exsolved (Figure $7 \mathrm{~b}$ ).

The intermediate compressibility slope, $C_{\mathrm{cgas}}$, was measured at $0.13 . \sigma_{\mathrm{p} 2}^{\prime}$ was measured at $345 \mathrm{kPa}$ when $\sigma_{\mathrm{p} 0}^{\prime}$ reached $1100 \mathrm{kPa}$ (cycle 3).

P-wave velocities have different trends with void ratio depending on the cycle (Figure 7b). Cycle 1, where Pwave velocities were measured on water-saturated sediments, differs from the other cycles. The impact of free gas on acoustic velocities is again displayed in this test as P-wave velocity trend with void ratio have a gentler slope when sediments contain free-gas (Figure $7 \mathrm{~b}$ ). Once $\mathrm{S}_{\mathrm{g}}$ equals zero, $\mathrm{P}$-wave velocities are attenuated until reaching the normal compression trend (Figure 7a,b,c). Moreover, the cycle having the biggest gas saturation is not the one displaying the smallest values of $V_{p}$. Instead, P-wave velocities decrease after each gas exsolution showing that sediments did not recover their normal acoustic response after free gas dissipated and reloading.

Only two cycles were completed during test\#5. The first cycle is not displayed in Figure 9a as the pressure difference between the two ends of the sample was maintained during the whole cycle for carbonated water circulation. Therefore, the calculated $\sigma_{v}^{\prime}$ for this cycle is not representative. However, total depressurization completed on the sample $(\Delta \mathrm{u}=-800 \mathrm{kPa})$, triggered a complete remolding of sediments as shown in Figure 10 . The sample fractured completely and so intensely that it resembled slurry. The total swelling recorded was $9.5 \mathrm{~mm}$, corresponding to gas saturation of $38 \%$, which is the maximum value obtained in this study. For this reason, test\#5 is regarded as the extreme scenario. Two intermediate compressibilities were measured. The first one corresponds to the fracture closing and has a sub-vertical slope (Figure 9a). The second one has a slope greater than the virgin compaction curve. Finally, from $\sigma_{v}^{\prime}=150 \mathrm{kPa}$ to the end of the loading, sediments follow the normal compression trend (grey line in Figure 9a). The normal compressibility was recovered when $\mathrm{S}_{\mathrm{g}}$ was already equal to zero for $50 \mathrm{kPa}$ 

dissipation even though they displayed a lower gas saturation.
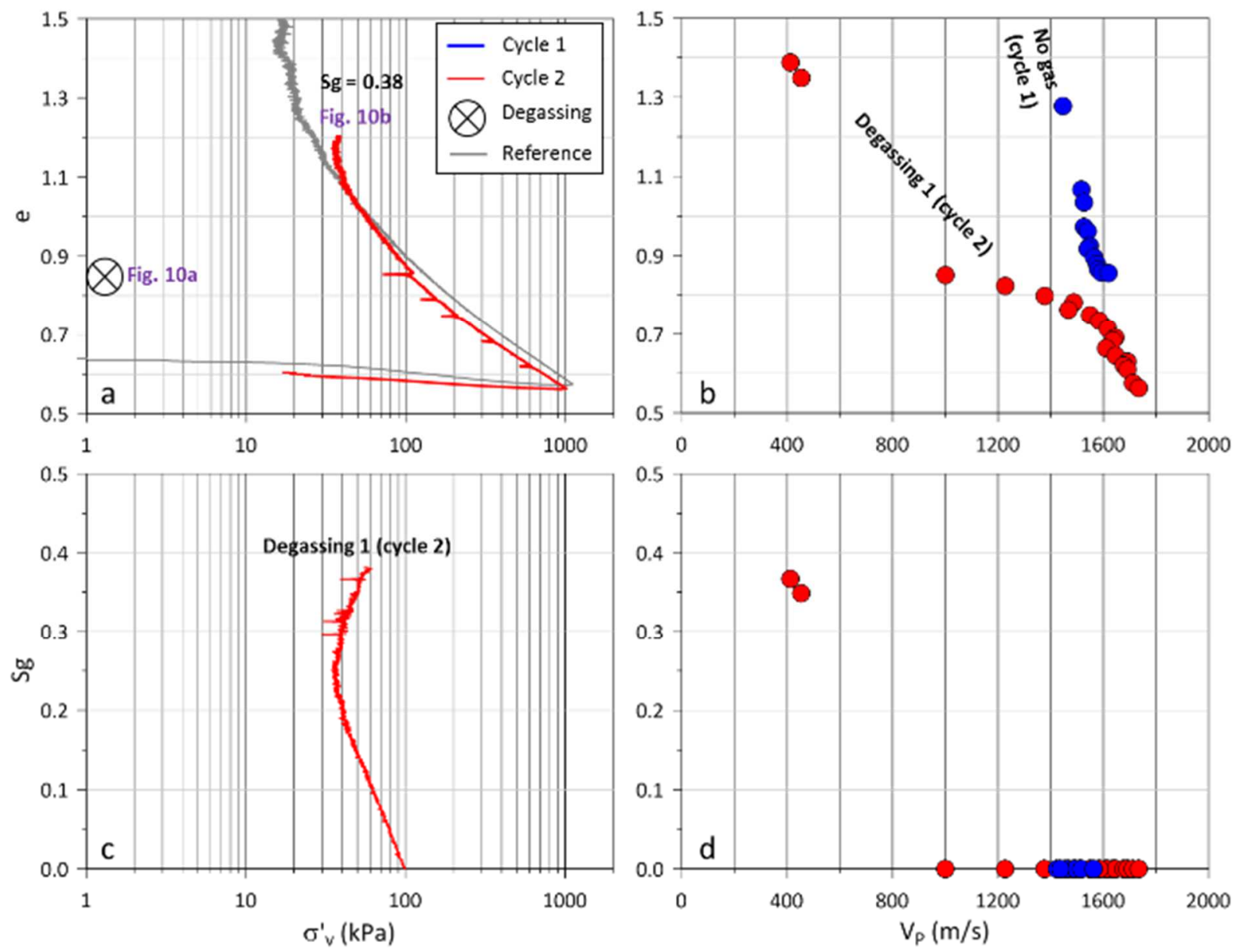

Figure 9: Results for test\#5 with 2 load/unload cycles. Each color represents one load/unload cycle. a: void ratio (e) versus vertical effective stress $\left(\sigma_{v}\right)$ b: void ratio-versus $P$ wave velocity $\left(V_{p}\right)$; c: degree of gas saturation $\left(S_{g}\right)$ versus $\sigma_{v}^{\prime}$ and $d: S_{g}$ versus $V_{p}$. The grey line in (a) represents the reference consolidation test.

P-wave velocities were recorded throughout the two cycles. Figure 9c, d clearly shows the difference in velocity magnitudes before and after exsolution. P-wave velocities recorded after exsolution decreased by more than $50 \%$ for high void ratios $(e>1)$. After gas dissipation $\left(\sigma_{v}^{\prime}>100 \mathrm{kPa}\right.$, Figure 9c), P-wave velocity for cycle 2 quickly increases with decreasing void ratio and recovers a trend parallel to the water-saturated reference when the minimum void ratio for cycle 1 is exceeded (Figure 9b). Therefore, gas exsolution seems to disturb P-wave velocities even after all the free gas has dissipated.

The slopes for the two intermediate compressibilities were measured. The closing of fractures corresponds to a slope $C_{\text {crac }}$ of 1.6 . The intermediate compressibility slope, $C_{\text {cgas, }}$ was measured at 0.5 . Therefore, a $\sigma_{p 1}^{\prime}$ of $42 \mathrm{kPa}$ was calculated, the initial preconsolidation pressure, $\sigma_{p 0}^{\prime}$, being around $60 \mathrm{kPa}$. $\sigma_{\mathrm{p} 2}^{\prime}$ was not calculated as the classical method for its determination is not applicable in this case. However, due to the slurry aspect of the sample after gas 
exsolution (which led to the maximum measured $S_{g}$ of this study) and based on how the compaction curve fits the reference, this test is considered as representative of a critical remolded state where the sediment has entirely lost its preconsolidation pressure. We consider, for this test, $\sigma_{\mathrm{p} 2}^{\prime}=0$.
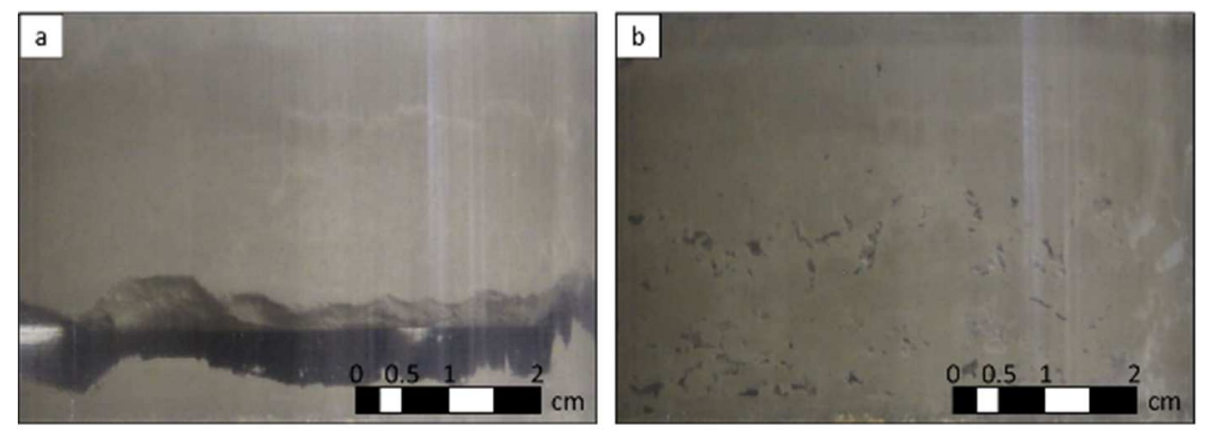

Figure 10: Pictures of the sample during test 5. a: before complete depressurization (Figure 9a) showing the sediment aspect before gas exsolution. b: after complete depressurization (Figure 9a). The sample swelled by $9.5 \mathrm{~mm}$ under the effect of gas exsolution. Numerous fractures generated and sediments took a slurry aspect.

\section{Synthesis of experimental results}

\subsection{Fractures, sediment damage and remolding}

On the eleven conducted tests, fifteen exsolution events triggered under different conditions (e.g. different $\sigma_{p 0}^{\prime}$, different initial degree of gas saturation corresponding to different gas pressure $u_{\mathrm{g}}$, and different decompression $\Delta u$ ) created diverse fracture distributions, with varying size, shapes and numbers. The observations made on each experiment along with pre-existing conditions are summarized in Table 4.

We propose an empirical classification of fractures, based on the sample visible surface after exsolution. Based on the observations in Table 4, fractures generated by gas exsolution are classified in three different length categories:

1- Fractures longer than $1 \mathrm{~cm}$

2- Fractures between $1 \mathrm{~cm}$ and $0.5 \mathrm{~cm}$ long

3- Fractures shorter than $0.5 \mathrm{~cm}$.

Conversely, fracturing intensity is arbitrarily grouped in three sets defined as:

1- More than 10 visible fractures

2- Less than 10 fractures

3- No visible fractures. 

visible. Nevertheless, as the same classification was applied to all fracture networks, comparison between tests is

423 considered as representative of the actual fracturing intensity.

\begin{tabular}{|c|c|c|c|c|c|c|c|c|c|}
\hline Test & $\sigma_{p 0}^{\prime}(\mathrm{kPa})$ & $u_{g}(\mathrm{kPa})$ & $\Delta \mathrm{u}(\mathrm{kPa})$ & $\begin{array}{c}S_{g \max } \\
(\%)\end{array}$ & fracture type & Photo & Interpretation & $\begin{array}{l}\text { Fracture } \\
\text { length }\end{array}$ & $\begin{array}{l}\text { Fracture } \\
\text { intensity }\end{array}$ \\
\hline 2 & 118 & 350 & -350 & 10 & $\begin{array}{l}\mathrm{cm} \text {-scale connected } \\
\text { horizontal fractures. Not } \\
\text { numerous. Mainly at the } \\
\text { top of the sample. }\end{array}$ & * & & 1 & 2 \\
\hline 2 & 970 & 350 & -350 & 5 & $\begin{array}{l}\mathrm{cm} \text {-scale and very thin } \\
\text { rare fractures. }\end{array}$ & & & 2 & 2 \\
\hline 3 & 446 & 800 & -800 & 32 & $\begin{array}{l}\text { mm-scale horizontal } \\
\text { fractures. Numerous. } \\
\text { Homogeneously } \\
\text { distributed. }\end{array}$ & & & 2 & 1 \\
\hline 4 & 195 & 500 & -500 & 17 & $\begin{array}{l}\mathrm{mm} \text {-scale horizontal } \\
\text { fractures. Numerous. } \\
\text { Mainly on the top third } \\
\text { of the sample. }\end{array}$ & & & 2 & 1 \\
\hline 5 & 65 & 800 & -800 & 38 & $\begin{array}{l}\text { Numerous mm-scale } \\
\text { horizontal fractures. } \\
\text { Slurry aspect. } \\
\text { Completely remolded } \\
\text { sediment. }\end{array}$ & & & 2 & 1 \\
\hline 6 & 367 & 500 & -500 & 23 & $\begin{array}{l}\text { Numerous mm-scale } \\
\text { horizontal fractures. } \\
\text { Homogeneously } \\
\text { distributed. }\end{array}$ & & & 2 & 1 \\
\hline 7 & 398 & 800 & -400 & 20 & $\begin{array}{l}\mathrm{cm} \text {-scale horizontal } \\
\text { fractures. Not } \\
\text { numerous. Sample is cut } \\
\text { into two parts. }\end{array}$ & & _- & 1 & 2 \\
\hline 8 & 405 & 800 & -300 & 11 & No visible fractures. & & & 3 & 3 \\
\hline
\end{tabular}




\begin{tabular}{|c|c|c|c|c|c|c|c|c|c|}
\hline Test & $\sigma_{p 0}^{\prime}(\mathrm{kPa})$ & $u_{g}(k P a)$ & $\Delta \mathrm{u}(\mathrm{kPa})$ & $\mathrm{S}_{\text {gmax }}$ & fracture type & Photo & Interpretation & $\begin{array}{c}\text { Fracture } \\
\text { length }\end{array}$ & $\begin{array}{l}\text { Fracture } \\
\text { number }\end{array}$ \\
\hline 8 & 995 & 500 & -500 & 36 & $\begin{array}{l}\text { Numerous } \mathrm{cm} \text {-scale } \\
\text { horizontal fractures. }\end{array}$ & & & 1 & 1 \\
\hline 9 & 408 & 800 & -100 & 5 & No visible fractures. & & & 3 & 3 \\
\hline 9 & 895 & 700 & -250 & 17 & No visible fractures. & & & 3 & 3 \\
\hline 11 & 398 & 800 & -200 & 24 & $\begin{array}{l}\text { Few mm-scale fractures } \\
\text { distributed along a pre- } \\
\text { existing light color } \\
\text { horizontal layer. } \\
\text { Light area thickens } \\
\text { during exsolution. }\end{array}$ & & & 3 & 2 \\
\hline 11 & 806 & 600 & -200 & 18 & $\begin{array}{l}\text { Few } \mathrm{mm} \text {-scale to } \mathrm{cm} \text { - } \\
\text { scale fractures, } \mathrm{mm} \text { - } \\
\text { thick in the bottom edge } \\
\text { of the sample. }\end{array}$ & & & 2 & 2 \\
\hline 11 & 1071 & 400 & -400 & 22 & $\begin{array}{l}\text { Numerous cm-scale } \\
\text { fractures. Higher } \\
\text { fracture number and } \\
\text { thicker fractures on the } \\
\text { top half of the sample. }\end{array}$ & & $0.5-1 \mathrm{cn}$ & 1 & 1 \\
\hline
\end{tabular}

Table 4: Summary of observations related to fracture networks created during gas exsolution. Each fracture network was classified into three size categories (1: length $>1 \mathrm{~cm} ; 2: 0.5 \mathrm{~cm}<$ length $<1 \mathrm{~cm} ; 3$ : length $<0.5 \mathrm{~cm}$ ) and three fracture number groups (1: more than 10 fractures; 2: less than 10 fractures; 3: no fractures). Vertical scale is equivalent to the horizontal one on the pictures and their corresponding interpretations. Pictures were taken after each exsolution stage, across the Plexiglas cell.

\subsection{Effect of gas saturation on P-wave velocity}

The effect of free gas on the acoustic properties of marine sediments has been already widely studied (Helgerud, et al., 1999; Rebata-Landa, et al., 2012; Sultan, et al., 2012). Helgerud et al. (1999), based on previous works by Dvorkin et al. (1999) on elasticity of marine sediments, proposed an effective medium model to predict P-wave and S-wave velocities in sediments containing free gas and/or gas hydrates based on mineralogy, compressibility and initial void ratio.

We used this model to draw a chart for predicted P-wave velocity variation with void ratio for different values of $\mathrm{S}_{\mathrm{g}}$ (black lines in Figure 11a,b). The properties of sediments used in the modeling are summarized in Table 2 (mass\% of minerals, $C_{C}$ ). The average number of contacts per grain in a bulk unit (called $n$ in the Helgerud et al. (1999) model) 
was taken as equal to 4 . The mineralogy was simplified into three poles (clays, quartz and carbonates) and is indicated

in Table 2.

The P-wave velocities obtained from this study were plotted on the theoretical chart (Figure 11a,b). Two variables are considered in Figure 11: the degree of gas saturation (Figure 11a) and the maximum degree of gas saturation for each cycle (Figure 11b). Figure 11 also displays two examples of signals that are considered reliable for the $V_{p}$ determination: one with a high degree of gas saturation, after gas exsolution (Figure 11c), the other on a watersaturated and undisturbed sample, before gas exsolution (Figure 11d).
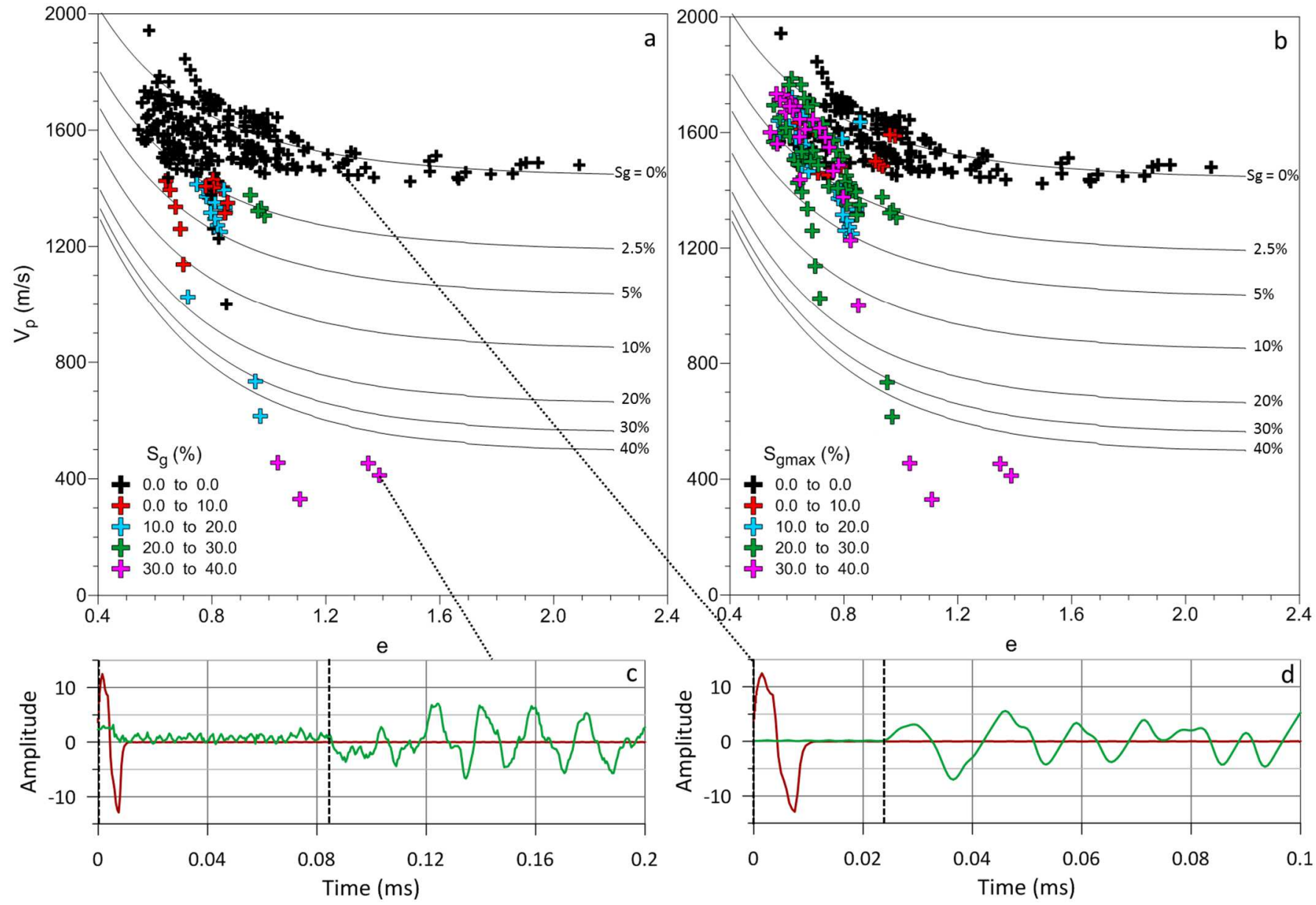

Figure 11: P-wave velocity $\left(V_{P}\right)$ versus void ratio (e). Colors stand for $(a) S_{g}(\%)$ and (b) $S_{g m a x}(\%)$. Black lines correspond to the evolution of $V_{P}$ with e for different values of $S_{g}$ based on the effective medium theory modeling (Helgerud, et al., 1999). (c) is the typical signal after gas exsolution, (d) is the typical signal after gas exsolution. Red line corresponds to the source signal, green line is the received signal.

The first observation is the good agreement between the curve corresponding to $\mathrm{S}_{\mathrm{g}}=0 \%$ on the chart and the P-wave velocity measurements obtained before exsolution (Figure 11a). Once exsolution occurs, P-wave velocities decrease drastically even for low values of $S_{\text {gmax }}(r e d$ and blue crosses on Figure $11 b)$. For the highest values of $S_{\text {gmax }}$ this decrease reaches $75 \%$ of the water-saturated value for a given void ratio. During the loading stage following exsolution, free gas is dissolved or expelled from the sample and $\mathrm{S}_{\mathrm{g}}$ decreases. Accordingly, $\mathrm{P}$-wave velocities increase 
once again (Figure 11a). Once $\mathrm{S}_{\mathrm{g}}$ reaches zero, P-wave velocities remain below the reference values and follow a trend between the curve corresponding to $S_{g}=0 \%$ and $S_{g}=2.5 \%$ (Figure 11a).

\subsection{Effect of degree of gas saturation on sediment compressibility}

During the tests completed during this study, a clear difference in sediment compressibility was observed

when comparing the state before and after gas exsolution. The compressibility after gas exsolution has a slope

comprised between $C_{C}$ and $C_{S}$ called $C_{\text {cgas. }}$. When fractures were abundant and/or large enough, a first compressibility

state was observed with slopes generally larger than $\mathrm{C}_{\mathrm{c}}$ and called $\mathrm{C}_{\mathrm{cfrac}}$.

For a comparative analysis, values of $\mathrm{C}_{\mathrm{cgas}}$ and $\mathrm{C}_{\mathrm{Cfrac}}$ obtained from the different tests were plotted against the maximum degree of gas saturation determined during each loading/unloading cycle $\left(\mathrm{S}_{\text {gmax }}\right)$ and were then compared saturated sediments.

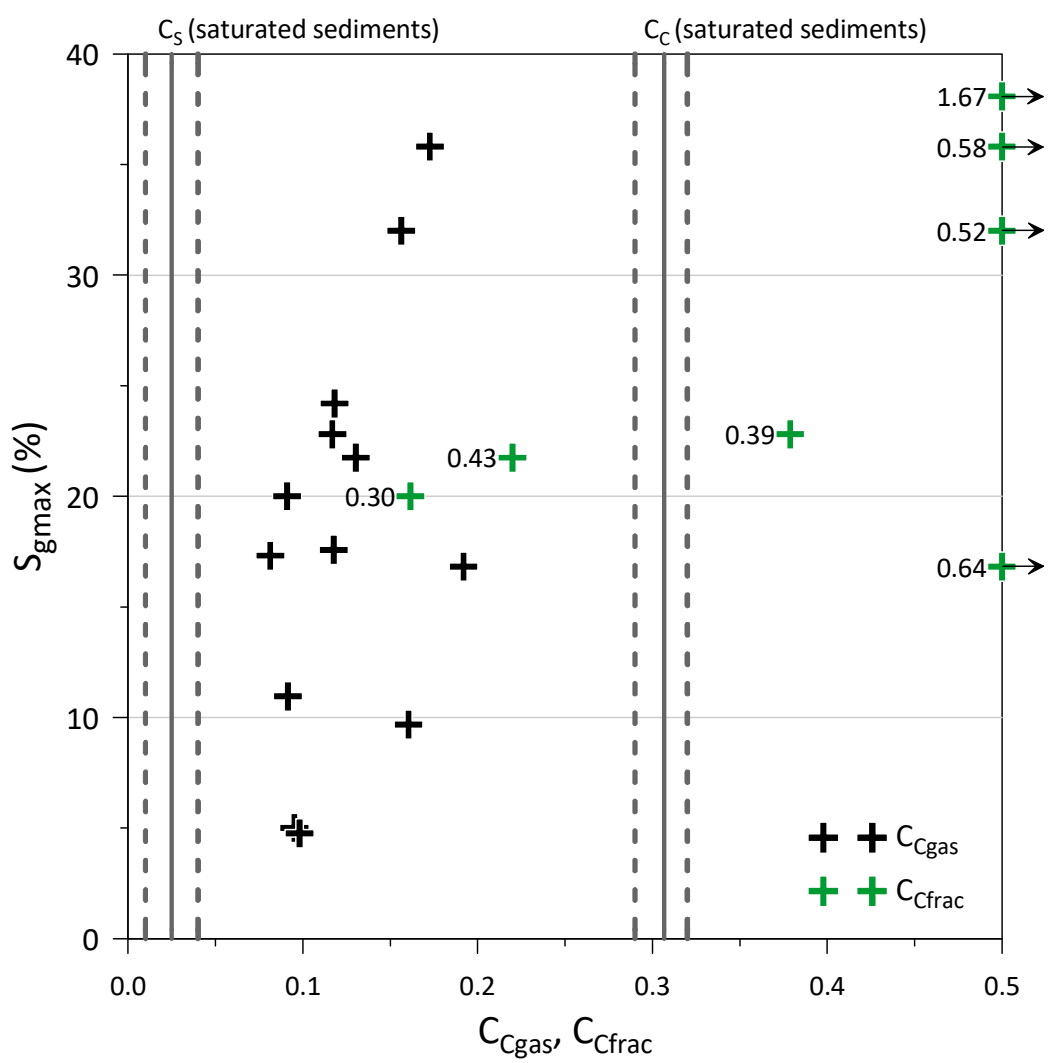

Figure 12: Compressibility versus $S_{\text {gmax }}(\%)$. Two type of compressibility are displayed. The grey vertical lines stand for the water-saturated sediments $C_{C}$ and $C_{S}$, the dotted lines being the maximal and minimal values obtained during the different tests. Values of $C_{C f r a c}$ are annotated as labels, since values above 0.5 were plotted at 0.5 to condense the graph.

$\mathrm{C}_{\text {cfrac }}$ values, except for two cases, are much larger than the $\mathrm{C}_{\mathrm{c}}$ of water-saturated sediments. This compressibility slope, observed after fracture initiation, corresponds to fracture closing. $\mathrm{C}_{\mathrm{cfrac}}$ obtained from tests 7 and 11 are lower than $C_{c}$. Test 7 fracture network is unique as a large fracture split the sample in half (Table 4), and 
contact between the two halves occurred when the fracture closed. For test 11, the fracture network is one of the densest, with centimeter-scale fractures. Before reloading (cycle 4), a permeability measurement under an imposed vertical hydraulic gradient partially closed the thinner fractures. This could be an explanation for the lower values of

$474 \quad$ C $_{\text {cfrac }}$ obtained on both tests.

\subsection{Hydraulic Conductivity versus degree of gas saturation}

Hydraulic conductivity $(\mathrm{K})$ data versus void ratio are shown in Figure 13a. $\mathrm{K}$ values obtained on the same sediment using the classical falling head method are plotted for comparison.

$\mathrm{K}$ measurements made before exsolution on water-saturated samples fit well with odometer measurements

(Figure 13a). After gas exsolution, $\mathrm{K}$ increases above the water-saturated sample trend. Thereafter, $\mathrm{K}$ decreases rapidly while resuming reloading, and reaches values below the trend of water-saturated samples. This decrease happened during a short time interval compared to the decrease of $\mathrm{K}$ during consolidation of the water-saturated sample. However, some of the K values acquired on water-saturated sediments seem to spread relatively to the trend curve in the same way. Nevertheless, Figure $13 \mathrm{~b}$ clearly shows that $\mathrm{K}$ increases with the $\mathrm{S}_{\mathrm{g}}$.
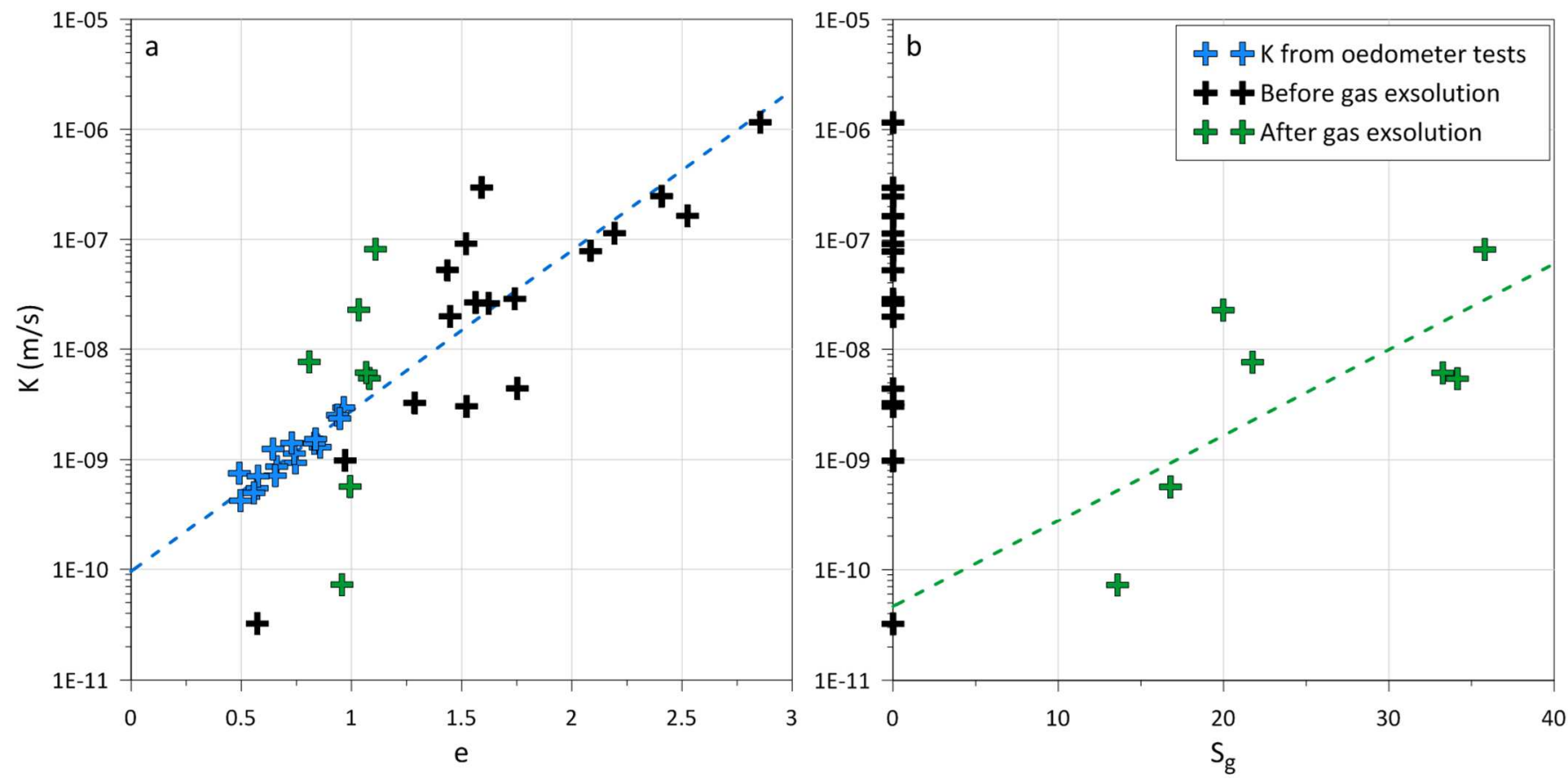

Figure 13: a: hydraulic conductivity, $K(\mathrm{~m} / \mathrm{s})$ versus void ratio. The blue dashed line is an exponential fit for hydraulic conductivities on watersaturated sediments obtained from oedometers (blue crosses). b: $K(\mathrm{~m} / \mathrm{s})$ versus $S_{g}(\%)$. 
In this paper, two preconsolidation pressures were determined. Before fracture closing, the intersection between the two slopes corresponding to $C_{\text {cfrac }}$ and $C_{\mathrm{cgas}}$ gives the $\sigma_{\mathrm{p} 1}^{\prime}$. After fracture closing, $\sigma_{\mathrm{p} 2}^{\prime}$ was determined by the intersection of the swelling curve and the virgin compaction curve.

To compare the two parameters over the entire set of test results, we normalized them with respect to $\sigma_{p 0}^{\prime}$

(Figure 14). The $\sigma_{p 1}^{\prime} / \sigma_{p 0}^{\prime}$ increases generally with increasing $S_{g m a x}$ but without a clear tendency (Figure 14a). Moreover, comparing these values to fractures in Table 4 shows that there is no clear relationship between fracture size and number and $\sigma_{\mathrm{p} 1}^{\prime} / \sigma_{\mathrm{p} 0}^{\prime}$.

Regarding the ratio between $\sigma_{\mathrm{p} 2}^{\prime}$ and $\sigma_{\mathrm{p} 0}^{\prime}$, results show that it decreases with increasing $\mathrm{S}_{\mathrm{gmax}}$, evidencing a preconsolidation pressure degradation with $S_{g \max }$ (Figure 14b). As a comparison, values from the study by Sultan, et al. (2012), on gassy sediments from the Gulf of Guinea were also added to Figure 14b. The results show a clear logarithmic trend with a strong determination coefficient of 0.75 and starting with a ratio equal to 1 when $\mathrm{S}_{\mathrm{g}}$ is zero. Values from the Gulf of Guinea are not exactly on the proposed trend. They were obtained on sediments having a completely different behavior in a water-saturated state, with a $C_{c}$ as high as 2 (Colliat, et al., 2011).
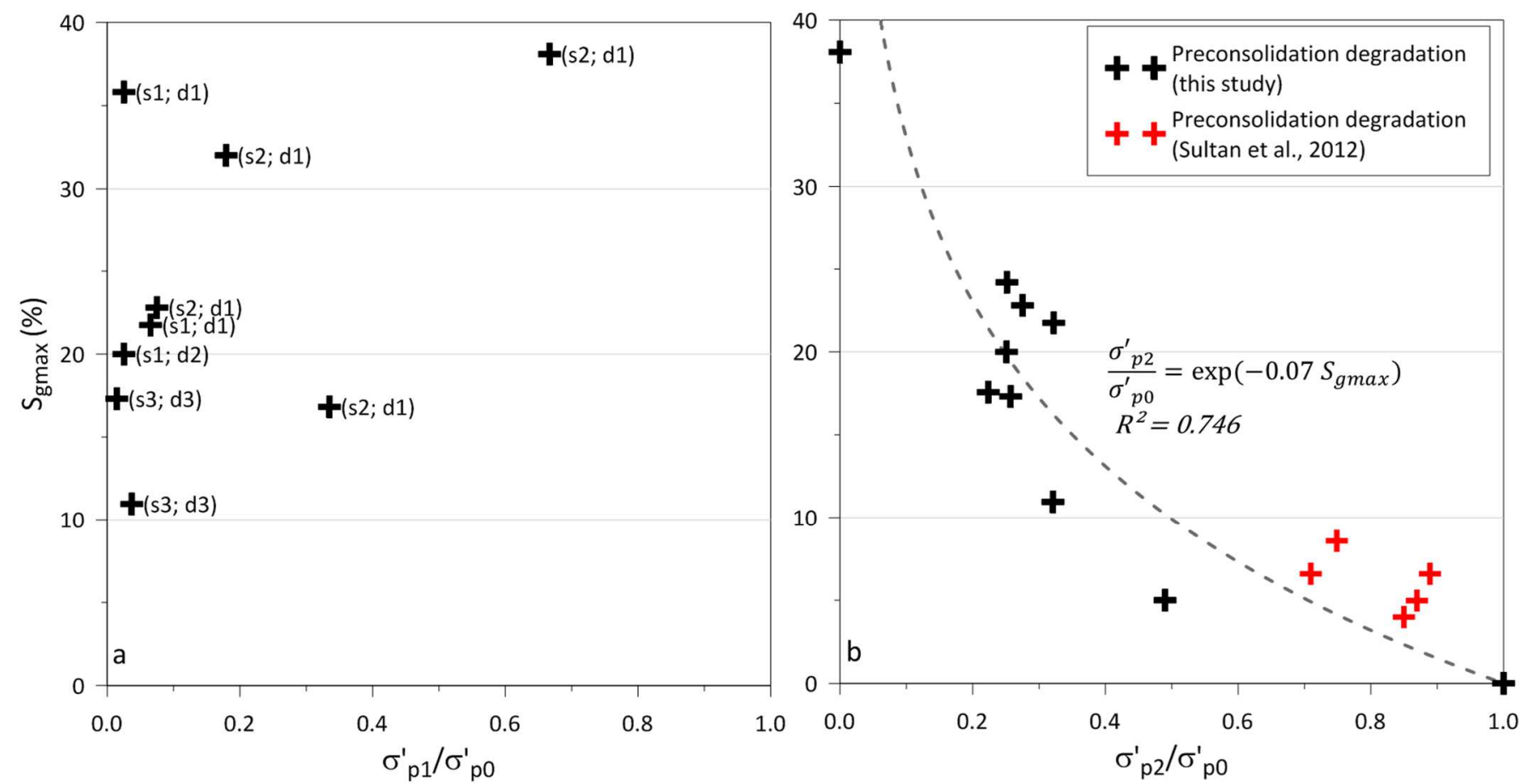

Figure 14: Preconsolidation ratio versus $S_{\text {gmax }}(\%)$. a: ratio between preconsolidation pressures calculated before fracture closing, $\sigma_{p 1}$, and the initial preconsolidation pressure, $\sigma_{p o}$. The labels correspond to the fracture classification given in Table 4. " $s$ " stands for the fracture length, " $d$ " for the fracture number. $b$ : ratio between preconsolidation pressures calculated after fracture closing, $\sigma_{p 2}^{\prime}$, and the initial preconsolidation pressure, $\sigma_{p o}$. Values from Sultan, et al. (2012) are also plotted as comparison (red crosses). An exponential fit of the study results shows a strong determination coefficient $\left(R^{2}\right)$. 


\subsection{Fracture size and number: main controlling factors}

The classification of fractures depending on their size and number was compared to the other parameters

used or obtained during the testing program (e.g. $\sigma_{\mathrm{p} 0}^{\prime}, \Delta \mathrm{u}$ or $\mathrm{S}_{\mathrm{gmax}}$; Table 4). The aim is to identify the main parameters controlling fracture size and number.

First, the length of fractures formed during this study range from one $\mathrm{mm}$ to $f e w \mathrm{~cm}$. Their observable thicker part corresponds to the center of the crack. Boudreau (2012) shows that growth and rise of gas bubbles in sediments is possible through fracture generation and that bubbles will be disk-shaped (also demonstrated by Katsman (2015)). Shin \& Santamarina (2011) as well as Jain \& Juanes (2009) show that gas-driven fractures are favored in fine-grained sediments. Therefore, gas exsolution and subsequent bubble generation and growth explains the shape of fractures. The observed cracks are not pre-existing discontinuities.

It clearly appeared during our study that the $S_{\text {gmax }}$ controls the fracture number: the larger the volume of freegas generated, the bigger the number of fractures. However, noticeable exceptions, such as test\#11, show that this is not the unique controlling factor for fracture number. A secondary parameter, the magnitude of depressurization $(\Delta u)$, seems to modulate the fracture number: the higher $\Delta u$, the more numerous the fractures. The two parameters are closely related as the $\mathrm{S}_{\mathrm{g}}$, corresponding to a volume of free gas generated during exsolution, is a direct consequence of the magnitude of depressurization.

From visual observations, three main fracture distributions can be discriminated (Table 4): dense and small fractures (tests 3, 4, 5 and 6), dense and large fractures (tests 8 and 11), and rare or inexistent fractures (tests 2, 8, 9, and 11).

The two denser distributions correspond to high $S_{\text {gmax }}$ values (more than $20 \%$ ) reached by complete depressurization. Test\#4 is an exception. It presents a very dense fracture network but only at the top of the sample. The sample was clearly not entirely saturated with carbonated water hence explaining fracture distribution. Besides, $\mathrm{S}_{\mathrm{gmax}}$ is calculated for the complete sample. Thus, applied to the fractured volume, $\mathrm{S}_{\mathrm{gmax}}$ is much higher than calculated. Smaller $\mathrm{S}_{\mathrm{gmax}}$ or partial depressurization lead to fracture networks with few or no fractures at all. 
dense fracture networks (high $\mathrm{S}_{\text {gmax }}$ ) shows that when $\sigma_{\mathrm{p} 0}^{\prime}$ is small (below $500 \mathrm{kPa}$ ) fractures are small. For higher $\sigma_{p 0}^{\prime}$

(above $500 \mathrm{kPa}$ ), these fractures get longer and thicker. Various studies on bubble growth and shape in marine sediments yielded the same results. Boudreau et al., (2005), Barry \& Boudreau (2010) and Katsman, (2015) demonstrate that bubble shape and size is mainly controlled by the mechanical properties of sediments. In particular, Katsman (2015) concludes that bubbles generating in weak sediments are small with higher surface-to-volume ratio (thin bubbles) while bubbles forming in stronger sediments tend to be larger and more spherical (larger).

Therefore, the controlling factors for fracture network architectures are $S_{\text {gmax }}$ and $\Delta u$ both controlling the number of fractures while $\sigma_{p 0}^{\prime}$ controls the size of the fractures.

\subsection{Gas exsolution/expansion: a permanent P-wave velocity attenuation?}

The presence of free gas has been always an issue when dealing with P-wave velocities (Sills, et al., 1991; Helgerud, et al., 1999; Sultan, et al., 2012). It provokes strong attenuation of the signal, ultimately preventing any signal propagation. Therefore, P-wave velocities are often used as a tool to detect free gas formation (Rebata-Landa, et al., 2012; Sultan, et al., 2012) as well as for estimating a degree of gas saturation (Lee \& Collett, 2006; Morgan, et al., 2012). The acoustic response of gassy sediments is theoretically supposed to join the trend of saturated sediments whenever $\mathrm{S}_{\mathrm{g}}$ becomes equal to zero.

The present study confirms this attenuating effect of free gas on P-wave velocities (Figure 11). The higher the $\mathrm{S}_{\mathrm{g}}$, the stronger the P-wave velocity attenuation. Besides, as free gas is dissolved and compressed during reloading, Pwave velocities increase once again. It shows the strong correlation between P-wave velocities and the $\mathrm{S}_{\mathrm{g}}$. Nevertheless, during reloading, when $\mathrm{S}_{\mathrm{g}}$ reaches zero, $\mathrm{P}$-wave velocities remain attenuated compared to the normal trend for water-saturated sediments (Figure 11a). Therefore, the damage generated by gas exsolution seems to delay the normal acoustic response of the sample.

The presence of fractures is a known factor for attenuating P-wave velocities in the perpendicular direction, independently of its filling material (Anderson, et al., 1974; Kahraman, 2002; Leucci \& Giorgi, 2006; Popp \& Salzer, 2007). Fracture generation may have triggered local changes in the shear modulus and/or the bulk modulus of the sediment (Huang, et al., 1995). Therefore, even after mechanical reloading and water saturation, long-term impact of fractures on the acoustic response is expected. 
with most of the P-wave velocities recorded after gas exsolution (Figure 11a). P-wave velocities are greatly overestimated (up to $300 \mathrm{~m} / \mathrm{s}$ ) for samples where dense fracture networks appeared during gas exsolution (Table 4) and they are underestimated (less than $100 \mathrm{~m} / \mathrm{s}$ ) for samples presenting rare or no fractures after gas exsolution (Table 4). P-wave velocities measured on samples with a higher degree of gas saturation present a signal that can be misleading. This may lead to errors in measurement that partly explain the differences observed with the model $(\approx 100 \mathrm{~m} / \mathrm{s})$. Considering the potential errors in measuring P-wave velocities for gassy samples, the Helgerud model is in adequacy with the measurements made on samples without or with rare fractures. The impact of fractures and discontinuities in the sample over P-wave velocities is responsible for the rest of the discrepancy, as modeled values are calculated for a homogeneous medium.

Thus, sediment damage caused by gas exsolution (through fractures, or with no visible markers), seems to have a durable impact on acoustic properties of sediments.

\subsection{Gas exsolution/expansion effects on sediment compressibility}

Sultan, et al. (2012) have clearly identified the impact of gas exsolution on the compressibility of clayey sediments. Experimental data of Sultan, et al. (2012) showed that after gas exsolution, the compressibility of the sediments increased significantly and is between the swelling index and the compression index of the initial intact sediments. This compressibility degradation was interpreted as being the result of sediment damaging during free gas generation. Previous experiments also highlighted a decay of compressibility with the presence of gas bubbles in soft marine clays (Sills, et al., 1991; Nava Castro, et al., 2013; Liu, et al., 2016). They concluded that gas bubbles bear part of the load applied on the sample and that soil compressibility measured on gassy sediment is primarily due to bubble compression and secondarily due to normal sediment compression, implying water expulsion. The presence of free gas in sediments was also proved to be responsible for a delay in consolidation. As gas escapes or dissolves, consolidation happens faster (Sills, et al., 1991; Nava Castro, et al., 2013).

This study showed that gas exsolution creates two intermediate compressibilities after fracture generation $\left(\mathrm{C}_{\mathrm{Cfrac}}\right.$ and $\left.\mathrm{C}_{\mathrm{Cgas}}\right)$ and only one when no fractures appeared ( $\left.\mathrm{C}_{\mathrm{cgas}}\right)$ (Figure $5 \mathrm{a}$, Figure $7 \mathrm{a}$ and Figure $\left.9 \mathrm{a}\right)$. The formation of fractures strongly impacted the compressibility of sediments. $\mathrm{C}_{\mathrm{cfrac}}$ were only measured for dense fracture networks and were generally higher than $C_{C}$ (Figure 12). Conversely, fracture number affected the compressibility after fracture 
closure $\left(\mathrm{C}_{\mathrm{cgas}}\right)$. For equivalent $\mathrm{S}_{\text {gmax }}$, higher $\mathrm{C}_{\mathrm{cgas}}$ were recorded for higher number of fractures (Table 4 and Figure 12$)$. $\mathrm{C}_{\mathrm{Cgas}}$ was always comprised between $\mathrm{C}_{\mathrm{C}}$ and $\mathrm{C}_{\mathrm{S}}$ (Figure 12 ).

Nevertheless, $\mathrm{C}_{\mathrm{cgas}}$ were also measured when no fractures were generated in the sediments. This shows that if fractures have an impact on the compressibility of sediments, the main controlling factor is the presence of gas. Indeed, this study shows that when $\mathrm{S}_{\text {gmax }}$ increases, $\mathrm{C}_{\text {cgas }}$ increases (Figure 12 ). For low $\mathrm{S}_{\mathrm{gmax}}, \mathrm{C}_{\mathrm{Cgas}}$ is closer to the swelling index of water-saturated sediments. This correlation was also noted by Hight \& Leroueil (2003) during loading of a sample with occluded gas bubbles. Therefore, gas exsolution tends to destroy the elastic behavior of sediments.

Test\#5 displayed an extreme behavior with a slurry aspect after gas exsolution and a $\mathrm{C}_{\mathrm{cgas}}$ higher than $\mathrm{C}_{\mathrm{c}}$. The virgin compaction curve was reached very fast compared to other tests (Figure 9a) showing that, after gas exsolution in test\#5, the sediments behaved as the initial remolded sediment.

Moreover, compressibility recovers a normal trend once $\sigma_{p 0}^{\prime}$ is reached, long after $\mathrm{S}_{\mathrm{g}}$ reached zero. Hight \& Leroueil (2003) demonstrated that once gas bubbles collapsed during reloading of a sample containing occluded gas bubbles, it recovers its normal $C_{c}$. The difference in this study is that free gas is concentrated along fracture planes and is not in the form of occluded gas bubbles. Therefore, as for P-wave velocity attenuation, the delay in compressibility recovery may be due to a permanent impact of fractures and damage caused by gas exsolution.

\subsection{Gas exsolution/expansion effects on sediment permeability}

Permeability of sediments can be affected by several mechanisms. Normal consolidation of sediments results in a decrease in hydraulic conductivity (Olsen, 1960; Chu, et al., 2002), contrarily to the presence of fractures, which may enhance this permeability depending on the fracture orientation relative to hydraulic gradient (Alfaro \& Wong, 2001). Besides, free gas in fine-grained sediments were proved to be a factor for permeability reduction (Egermann \& Vizika, 2000; Naylor, et al., 2000; Hight \& Leroueil, 2003; Jang \& Santamarina, 2014). If free gas accumulates in clayey layers, a capillary seal may form (a gas cap), generating an effective permeability even lower than the intrinsic permeability of the clayey layer (Revil, et al., 1998; Cathles, 2001).

Gas exsolution triggered the formation of horizontal millimeter to centimeter-scale fractures. Their orientation corresponds to a direction orthogonal to the possible fluid expulsion, which is not favorable to an increase in permeability. However, as observation of the fracture network was only possible at the sample surface, it is possible 
that fluid pathways created through connections between fractures, thus explaining the observed increase in permeability right after gas exsolution (Figure 13). These fractures were filled with free gas after gas exsolution, which may rather be a parameter in favor of a decrease in permeability. However, we do observe an increase in sample permeability just after fracture creation showing that gas filling the fractures may be in a continuous phase through an interconnected fracture network (Jang \& Santamarina, 2014).

During reloading, the rapid decrease in permeability (Figure 13) is probably related to the closing of fractures, and the consequent reduction of fluid pathways. Consequently to fracture closing, trapping of free gas in reduced areas changes free-gas distribution from a continuous phase to a more discrete distribution, a factor that was proved by Jang \& Santamarina (2014) to reduce sample permeability. The creation of potential capillary seals along the former fracture planes could explain the hydraulic conductivity values that are below the normal trend (Cathles, 2001).

Therefore, gas exsolution provokes an increase in permeability through fracture creation, creating preferential pathways. Then, reloading quickly reduces permeability due to fracture closure and capillary sealing as a consequence of free gas being captured in a discrete distribution.

\subsection{Gas exsolution/expansion effects on preconsolidation pressure and the consequence in terms} of shear strength

Besides the fracture formation that has already been discussed, gas exsolution has an impact on the preconsolidation pressure of sediments, showing the degree of sediment damage caused.

Before fracture closing, the degradation of sediment preconsolidation pressure is significant but seems to decrease with $\mathrm{S}_{\mathrm{gmax}}$ (Figure 14a). However, no clear trend appears. Except for one value, corresponding to test\#5, all the ratios are below 0.35 . It tends to indicate that at $35 \%$ of the $\sigma_{p 0}^{\prime}$ fractures are closed as $\sigma_{p 1}^{\prime}$ indicates a degradation connected to fracture closing. The sample of test\#5 was completely fractured during gas exsolution explaining the high value for the $\sigma_{p 1}^{\prime} / \sigma_{p 0}^{\prime}$ ratio: fractures took more time to close.

$\sigma_{p 2}^{\prime}$ was measured after fracture closing, therefore it evaluates the part of sediment damage that is visually imperceptible. The ratio between $\sigma_{\mathrm{p} 2}^{\prime}$ and $\sigma_{\mathrm{p} 0}^{\prime}$ correlates with $\mathrm{S}_{\mathrm{gmax}}$ through a logarithmic law (Figure 14b): the bigger $\mathrm{S}_{\mathrm{gmax}}$, the more the sediment was remolded, recording a decrease in preconsolidation pressure. This type of relation was already noted on sediments from the Gulf of Guinea (Sultan, et al., 2012) but at lower $\mathrm{S}_{\text {gmax }}$ (below 10\%). Besides, 
several other studies demonstrated this decrease in presconsolidation pressure with an increasing degree of gas saturation (Lunne, et al., 2001; Hight, et al., 2002). For Hight \& Leroueil (2003), it is mainly the result of damage due to bubble-growth in the sediments, the degree of damage being related to the initial level of structure. The initial level of structure may be the explanation for the differences observed between the measurements made during this study and the results obtained by Sultan, et al. (2012) on a different sediment.

This study showed, for different sediments and at a higher $S_{\text {gmax }}$ that a complete loss of preconsolidation pressure is feasible. For $38 \%$ of $\mathrm{S}_{\mathrm{gmax}}$, preconsolidation pressure was completely lost, showing that sediments were entirely remolded by gas exsolution. The corresponding sample (test\#5) had a slurry aspect right after gas exsolution and displays extreme behavior in terms of compressibility and sediment damage.

Therefore, the experimental results confirm that gas exsolution causes sediment damage and remolding. For strong gas exsolution, leading to high $\mathrm{S}_{\text {gmax }}$, sediments can even reach a state where they entirely lose their preconsolidation pressure.

Wheeler (1988) showed that methane bubbles might decrease or increase the undrained shear strength of reconstituted silty-clay samples. This was shown to depend on the level of total and effective stress. In the Wheeler (1988) experiments, gas bubbles were formed artificially by using the zeolite molecular sieve technique. Gas naturally formed in sediments or was generated by circulation of carbonated water. Subsequent decompression was shown to negatively affect the undrained shear strength. Lunne, et al. (2001), Hight, et al. (2002) and Sultan, et al. (2012) all point out that the degree of gas saturation significantly reduces preconsolidation pressure and shear strength.

Sultan \& Garziglia (2014) proposed a constitutive model to simulate the mechanical behavior of gassy sediments where preconsolidation pressure is the main parameter controlling yield surface and therefore shear strength of the sediment. By introducing to a conventional Cam-Clay type model the "preconsolidation pressure degree of gas saturation" logarithmic relationship equivalent to the one shown in Figure $14 \mathrm{~b}$, they were able to reproduce the observed data published by Lunne, et al. (2001), Hight, et al. (2002) and Sultan, et al. (2012). Data shown in Figure 14b highlight the important consequence of gas formation on the shear strength of the sediment from the AMV where the damage due to bubble growth may strongly decrease its shear strength. A $S_{g m a x}$ of $38 \%$ seems to be 
the upper limit for complete destruction of the structure and therefore the shear strength of AMV sediments and favoring mud generation.

\section{Conclusions}

This study investigates the impact of gas exsolution on the mechanical behavior of mud samples recovered on mudflows expelled from the Absheron Mud Volcano. The goal was to understand the factors that control fine-grained sediment damaging, and to quantify and determine the criteria by which we may determine that sediments are completely remolded, and considered as changed into mud. Eleven consolidation tests using a novel experimental apparatus allowed to generate free gas under different consolidation conditions. Results show that:

1- Fracture number is controlled by the degree of gas saturation, while preconsolidation pressure mainly controls fracture length.

2- Gas exsolution provokes sediment damage (through fracture emplacement and loss of preconsolidation pressure) and it increases with the degree of gas saturation while the elastic modulus of sediments is partly lost. Shear strength is also expected to decrease as a consequence of sediment damage.

3- Acoustic response remains degraded long after free gas has entirely dissipated from the sample. Compressibility is also durably modified, reaching normal trends only when initial preconsolidation is exceeded. Permeability first increases through fracture creation, but quickly deteriorates due to the presence of gas leading to capillary sealing during reloading. Therefore, sediments do not recover entirely from gas exsolution damage during reloading.

4- During testing, critical behavior was observed for a degree of gas saturation of $38 \%$. Gas exsolution triggered complete remolding of sediments (entire loss of preconsolidation pressure and therefore its shear strength) that took a slurry aspect. The same test displayed the highest compressibility at the beginning of reloading. Its compressibility trend was close to the initial compaction behavior whilst sediments had not yet compacted. Therefore, gas exsolution alone was able to generate mud from compacted fine-grained sediments.

Our experimental results showed that gassy fine-grained sediments with discontinuous gas phase may take place for Sg greater than $15 \%$. We show that such an experimental study can help determine the criteria for mud 
generation under laboratory conditions and on a particular sediment sample: mud expelled from the Absheron Mud Volcano. These criteria can be implemented into numerical models, integrating mechanical behaviors under the geological conditions observed and determined in the field. Ultimately, this experimental study offers a unique opportunity to quantify the volume of gas required to generate the volume of mud at depth that was extruded to form the studied Absheron Mud Volcano.

\section{Acknowledgments}

Data describing the natural mud properties are available at the following link: https://figshare.com/articles/Absheron_mud_analysis/7448153. This study was conducted in the scope of the PhD of Arthur Blouin under the joint direction of the Pau University (E2S-UPPA), Ifremer and Total S.A. The authors would like to thank Claire Fialips for the mud mineralogy analysis, Mickaël Rovere for his help during compressibility/permeability analyses, as well as Mickaël Roudaut and Ronan Apprioual for the experimental set-up conception/assembly and their technical support. Constructive comments by the associate editor and two anonymous reviewers helped to improve the paper.

\section{References}

Alfaro, M. C. and Wong, R. C. K. (2001) 'Laboratory studies on fracturing of low-permeability soils', Canadian Geotechnical Journal, 38(2), pp. 303-315. doi: 10.1139/cgj-38-2-303.

Anderson, D. L., Minster, B. and Cole, D. (1974) 'The effect of oriented cracks on seismic velocities', Journal of Geophysical Research, 79(26), pp. 4011-4015.

ASTM International (1996) ‘D 2435 - 96 - Standard test method for one-dimensional consolidation properties of soils', American Society for Testing and Materials. West Conshohocken, 04.08, pp. 196-205. doi: 10.1520/D243596.

Barry, M. and Boudreau, B. P. (2010) 'First-order description of the mechanical fracture behavior of finegrained surficial marine sediments during gas bubble growth', Journal of Geophysical Research: Atmospheres, 115, pp. 1-10. doi: 10.1029/2010JF001833.

Blouin, A. et al. (2019) 'Evolution model for the Absheron mud volcano : from in - situ observations to 
numerical modeling', Journal of Geophysical Research: Earth Surface, 124(3), pp. 766-794. doi: 10.1029/2018JF004872.

Boggess, R. and Robertson, P. K. (2011) 'CPT for Soft Sediments and Deepwater Investigations', Offshore Technology Conference, 21244(May), pp. 2-5.

Boudreau, B. P. et al. (2005) 'Bubble growth and rise in soft sediments', Geology, 33(6), pp. 517-520. doi: 10.1130/G21259.1.

Boudreau, B. P. (2012) 'The physics of bubbles in surficial , soft, cohesive sediments', Marine and Petroleum Geology. Elsevier Ltd, 38(1), pp. 1-18. doi: 10.1016/j.marpetgeo.2012.07.002.

Capaccioni, B. et al. (2017) 'Sand volcano generated by a violent degassing from methane-saturated aquifers: The case study of Medolla (Modena, Italy)', Engineering Geology. Elsevier B.V., 221(May 2012), pp. 91-103. doi: 10.1016/j.enggeo.2017.02.027.

Cathles, L. M. (2001) 'Capillary seals as a cause of pressure compartmentation in sedimentary basins', in Petroleum Systems of Deep-Water Basins: Global and Gulf of Mexico Experience. 21st Annual Bob F. Perkins Research Conference. Gulf Coast Section of the Society of Economic Paleontologists and Mineralogists, pp. 561-572. doi: 10.5724/gcs.01.21.0549.

Chan, C. M. (2012) 'On the intepretation of shear wave velocity from bender element tests', Acta Technica Corviniensis - Bulletin of Engineering, 5(1), pp. 29-34. Available at: http://acta.fih.upt.ro/pdf/2012-1/ACTA-2012-103.pdf.

Chu, J. et al. (2002) 'Consolidation and Permeability Properties of Singapore Marine Clay', (September), pp. 724-732.

Colliat, J.-L. et al. (2011) 'Gulf of Guinea deepwater sediments: Geotechnical properties, design issues and installation experiences', in White, D. and Gourvenec, S. (eds) Frontiers in Offshore Geotechnics II. London: Taylor \& Francis Group, pp. 59-86.

Cuss, R. et al. (2014) 'Experimental observations of mechanical dilation at the onset of gas flow in CallovoOxfordian claystone', Clays in Natural and Engineered Barriers for Radioactive Waste Confinament. Geological Society, London, Special Publications, 400(iii), pp. 507-519. doi: 10.1144/SP400.26. 
Dvorkin, J. et al. (1999) 'Elasticity of marine sediments: Rock physics modeling', Geophysical Research Letters, 26(12), pp. 1781-1784.

Egermann, P. and Vizika, O. (2000) ‘A NEW METHOD TO DETERMINE CRITICAL GAS SATURATION AND RELATIVE PERMEABILITY DURING DEPRESSURIZATION IN THE NEAR-WELLBORE REGION', in SPE annual technical conference and exhibition. Society of Petroleum Engineers, pp. 1-12. doi: doi:10.2118/63149-MS.

Esrig, M. I. and Kirby, R. C. (1977) 'Implications of gas content for predicting the stability of submarine slopes', Marine Geotechnology, 2(1-4), pp. 81-100. doi: 10.1080/10641197709379771.

Feng, T. W. (2000) 'Fall-cone penetration and water content relationship of clays', Geotechnique, 50(2), pp. 181-187. doi: https://doi.org/10.1680/geot.2000.50.2.181.

Grozic, J. L. H., Nadim, F. and Kvalstad, T. J. (2005) ‘On the undrained shear strength of gassy clays', Computer and Geotechnics, 32, pp. 483-490. doi: 10.1016/j.compgeo.2005.10.002.

Grozic, J. L. H., Robertson, P. K. and Morgenstern, N. R. (2000) 'Cyclic liquefaction of loose gassy sand', Canadian Geotechnical Journal, 37, pp. 843-856.

Helgerud, M. B. et al. (1999) 'Elastic-wave velocity in marine sediments with gas hydrates: Effective medium modeling', Geophysical Research Letters, 26(13), pp. 2021-2024.

Hight, D. W., Hamza, M. M. and El Sayed, A. S. (2002) 'Engineering characterization of the Nile Delta clays', in Nakase, A. and Tsuchida, T. (eds) Coastal geotechnical engineering in practice. Lisse, the Netherlands: Swets \& Zeitlinger, pp. 149-162.

Hight, D. W. and Leroueil, S. (2003) 'Characterisation of soils for engineering purposes', in Tan, T. S. et al. (eds) Characterisation and engineering properties of natural soils - volume 1. Lisse, The Netherlands: Swets \& Zeitlinger, pp. $255-360$.

Hong, Y. et al. (2017) 'Effect of initial pore pressure on undrained shear behaviour of fine-grained gassy soil', Canadian Geotechnical Journal, 54(11), pp. 1592-1600.

Huang, T. H., Chang, C. S. and Yang, Z. Y. (1995) 'Elastic Moduli for Fractured Rock Mass', Rock Mechanics and Rock Engineering, 28(3), pp. 135-144. 
Jain, A. K. and Juanes, R. (2009) 'Preferential Mode of gas invasion in sediments : Grain-scale mechanistic model of coupled multiphase fluid flow and sediment mechanics', 114(1), pp. 1-19. doi: 10.1029/2008JB006002.

Jang, J. and Santamarina, J. C. (2014) 'Evolution of gas saturation and relative permeability during gas production from hydrate-bearing sediments: Gas invasion vs. gas nucleation', Journal of Geophysical Research: Solid Earth, 119, pp. 116-126. doi: 10.1002/2013JB010480.Received.

Judd, A. G. and Hovland, M. (2007) 'Seabed fluid flow: the impact of geology, biology and the marine environment', Cambridge University Press, (February), pp. 1-442. doi: 10.1007/s00254-004-1086-0.

Kahraman, S. (2002) 'The effects of fracture roughness on P -wave velocity', 63, pp. 347-350.

Katsman, R. (2015) ‘Correlation of shape and size of methane bubbles in fine-grained muddy aquatic sediments with sediment fracture toughness', Journal of Structural Geology. Elsevier Ltd, 70, pp. 56-64. doi: 10.1016/j.jsg.2014.11.002.

Kirkham, C. B. (2015) 'A 3D seismic interpretation of mud volcanoes within the western slope of the Nile Cone'. Cardiff University.

Kopf, A. J. (2002) 'Significance of mud volcanism', Reviews of Geophysics, 40(2), p. 1005. doi: 10.1029/2000RG000093.

Lee, M. W. and Collett, T. S. (2006) 'Gas hydrate and free gas saturations estimated from velocity logs on hydrate ridge, Offshore Oregon, USA', in Tréhu, A. M. et al. (eds) Proceedings of the Ocean Drilling Program, Scientific Results. College Station, Texas: Ocean Drilling Program, pp. 1-25. doi: doi:10.2973/odp.proc.sr.204.103.2006.

Leucci, G. and Giorgi, L. De (2006) 'Experimental studies on the effects of fracture on the P and S wave velocity propagation in sedimentary rock ( "Calcarenite del Salento ")', 84, pp. 130-142. doi: 10.1016/j.enggeo.2005.12.004.

Liu, K., Xue, J. and Yang, M. (2016) 'Deformation behaviour of geotechnical materials with gas bubbles and time dependent compressible organic matter', Engineering Geology. Elsevier B.V., 213, pp. 98-106. doi: 10.1016/j.enggeo.2016.09.003.

Lunne, T. et al. (2001) 'Deepwater sample disturbance due to stress relief', in Proceedings of the 1st Annual Offshore Technology Conference. Houston, Texas, pp. 64-85. 
Lunne, T. (2010) 'The CPT in offshore soil investigations - a historic perspective', (May).

Mazzini, A. and Etiope, G. (2017) 'Mud volcanism: An updated review', Earth-Science Reviews. Elsevier B.V., 168, pp. 81-112. doi: 10.1016/j.earscirev.2017.03.001.

Mazzini, A., Etiope, G. and Svensen, H. (2012) 'A new hydrothermal scenario for the 2006 Lusi eruption, Indonesia. Insights from gas geochemistry', Earth and Planetary Science Letters. Elsevier B.V., 317-318(May 2006), pp. 305-318. doi: 10.1016/j.epsl.2011.11.016.

Morgan, E. C. et al. (2012) 'Estimation of free gas saturation from seismic reflection surveys by the genetic algorithm inversion of a P-wave attenuation model', 77(4).

Nageswaran, S. (1983) 'Effect of gas bubbles on sediment behavior'. University of Oxford.

Nava Castro, R. et al. (2013) 'Variation of Mechanical Properties of Soft Marine Clay with Methane Gas Content - OMAE2013-10800', in Proceedings of the ASME 2013 32nd International Conference on Ocean, Offshore and Arctic Engineering - OMAE2013. Nantes, pp. 1-9.

Naylor, P. et al. (2000) 'Relative permeability measurements for post-waterflood depressurisation of the Miller field, North Sea', in SPE annual technical conference and exhibition. Dallas, Texas: Society of Petroleum Engineers, pp. 491-497.

Olsen, H. W. (1960) 'Hydraulic Flow Through Saturated Clays', Clays and Clay Minerals, 9(1), pp. 131-161.

Popp, T. and Salzer, K. (2007) 'Anisotropy of seismic and mechanical properties of Opalinus clay during triaxial deformation in a multi-anvil apparatus', Physics and Chemistry of the Earth, 32, pp. 879-888. doi: 10.1016/j.pce.2006.04.022.

Rebata-Landa, V., Santamarina, J. C. and Asce, M. (2012) 'Mechanical Effects of Biogenic Nitrogen Gas Bubbles in Soils', (February), pp. 128-137. doi: 10.1061/(ASCE)GT.1943-5606.0000571.

Revil, A. et al. (1998) 'Capillary sealing in sedimentary basins: A clear field example', Geophysical Research Letters, 25(3), pp. 389-392.

Riboulot, V. et al. (2013) 'Sea-level change and free gas occurrence influencing a submarine landslide and pockmark formation and distribution in deepwater Nigeria', Earth and Planetary Science Letters. Elsevier, 375, pp. 78- 
91. doi: 10.1016/j.epsl.2013.05.013.

Ryzak, M. and Bieganowski, A. (2011) 'Methodological aspects of determining soil particle-size distribution using the laser diffraction method', Journal of Plant Nutrition and Soil Science, 174(4), pp. 624-633. doi: 10.1002/jpln.201000255.

Shin, H. and Santamarina, J. C. (2011) ‘Open-mode discontinuities in soils', Géotechnique Letters, 1, pp. 95-99. doi: http://dx.doi.org/10.1680/geolett.11.00014.

Sills, G. C. et al. (1991) 'Behaviour of offshore soils containing gas bubbles', Géotechnique, 41(2), pp. 227-241.

Sills, G. C. Ã. and Gonzalez, R. Ã. (2001) 'Consolidation of naturally gassy soft soil', Géotechnique, 51(7).

Skempton, A. W. (1944) 'Notes on the compressibility of clays', Quarterly Journal of the Geological Society of London, 100, pp. 119-135.

Sobkowicz, J. C. and Morgenstern, N. R. (1984) 'The undrained equilibrium behaviour of gassy sediments', Canadian Geotechnical Journal, 21, pp. 439-448.

Stewart, S. A. and Davies, R. J. (2006) 'Structure and emplacement of mud volcano systems in the South Caspian Basin', AAPG Bulletin, 90(5), pp. 771-786. doi: 10.1306/11220505045.

Sultan, N. et al. (2004) 'Triggering mechanisms of slope instability processes and sediment failures on continental margins: A geotechnical approach', Marine Geology, 213(1-4), pp. 291-321. doi: 10.1016/j.margeo.2004.10.011.

Sultan, N. and Garziglia, S. (2014) 'Mechanical behaviour of gas-charged fine sediments: model formulation and calibration', Géotechnique, 64(11), pp. 851-864. doi: 10.1680/geot.13.P.125.

Sultan, N., De Gennaro, V. and Puech, A. (2012) 'Mechanical behaviour of gas-charged marine plastic sediments', Géotechnique, 62(9), pp. 751-766. doi: 10.1680/geot.12.0G.002.

Thomas, S. D. (1987) 'The consolidation behaviour of gassy soil'. University of Oxford.

Tingay, M. et al. (2008) 'Triggering of the Lusi mud eruption: Earthquake versus drilling initiation', Geology, 36(8), pp. 639-642. doi: 10.1130/G24697A.1.

Tingay, M. et al. (2017) 'An alternative review of facts, coincidences and past and future studies of the Lusi 
841 eruption', Marine and Petroleum Geology, (December). doi: 10.1016/j.marpetgeo.2017.12.031.

843 doi: $10.1038 /$ ngeo2472.

Wheeler, S. J. (1988) 'The undrained shear strength of soils containing large gas bubbles', Géotechnique, 38(3), 845 pp. 399-413. 